\title{
ABINÕUd VILJAPUUDUSE LEEVENDAMISEKS EESTIMAA JA PÕHJA-LiIvimaA VALDAdes 1860. AASTATEL
}

\author{
Ülle Tarkiainen
}

Praeguse Eesti ala põllumajanduses oli kuni 19. sajandi teise pooleni kõige tähtsamal kohal teraviljakasvatus. Teravilja, eelkõige rukist, kasutati toiduks, kuid seda vajati ka viinapõletamisel. Kui varasematel aastasadadel olid ikaldused ja nendega kaasnenud toidupuudus üsna tavalised, siis 19. sajandi teiseks pooleks kadus Euroopas ühiskondlike ja põllumajanduslike muutuste tõttu näljahäda oht. Vaid raskemate loodusoludega ning poliitiliselt ja majanduslikult mahajäänud Euroopa põhja- ja idaosas olid ikalduste tagajärjed endiselt rasked. Ka Eesti ala tabasid 1860. aastate teisel poolel ikaldus ja sellega seotud näljahäda, mille all kannatas suur osa tolleaegsest rahvastikust.

See artikkel on valminud seoses Soome ja Eesti uurijate ühisprojektiga "Rahvastikukatastroofid Soomes ja Eestis 1860. aastatel" ${ }^{1}$, mille eesmärk oli 1860. aastatel aset leidnud näljahädade võrdlev käsitlemine. Soome 1867.-68. aasta näljahäda on aastate jooksul põhjalikult ja eri vaatenurkadest uurinud mitmed teadlased, näiteks Oiva Turpeinen, Antti Häkkinen, Miikka Voutilainen jt. ${ }^{2}$ Uuemates uurimustes ei keskenduta mitte ainult toidupuudusele või vilja jagamisega seotud probleemidele, vaid näljahäda puhkemist on vaadeldud osana suuremast protsessist ning uuritud on poliitilisi aspekte ja põhjuseid, miks näljahäda ei õnnestunud vältida. ${ }^{3}$

\footnotetext{
1 Vt täpsemalt Timo Myllyntaus, Marten Seppel, "Eesti-Soome uurimisprojekt: võrdlev pilguheit kahe naabermaa 19. sajandi ajaloole”, Tuna, 2 (2018), 144-146.

${ }_{2}$ Oiva Turpeinen, Nälkä vai tauti tappoi? Kauhunvuodet 1866-1868. Helsinki 1866-1868 (Helsinki: SHS, 1986); Antti Häkkinen, Vappu Ikonen, Kari Pitkänen, Hannu Soikkanen, Kun halla nälän tuskan toi. Miten suomalaiset kokivat 186o-luvun nälkävuodet (Helsinki: WSOY, 1991); Just a sack of potatoes? Crisis experiences in European societies, past and present, ed. by Antti Häkkinen (Helsinki: SHS, 1992); Antti Häkkinen, "Nälkävuodet, yhteisöt ja kuoleman kuvat", Suomalaisen kuoleman historia, toim Ilona Pajari, Jussi Jalonen, Riikka Miettinen, Kirsi Kanerva (Helsinki: Gaudeamus, 2019), 155-181.

3 Vt Miikka Voutilainen, Poverty, Inequality and the Finnish 1860s Famine, Jyväskylä Studies in Humanities, 287 (Jyväskyla: University of Jyväskylä, 2016), 18-27; Miikka
} 
Teine muutus on seotud viimastel aastakümnetel toimunud keskkonna- ja kliimauuringute arenguga, mistõttu on uurimise keskmesse järjest enam hakatud tõstma tolleaegseid keskkonnaolusid. Erilist tähelepanu on pööratud ka põllumajanduses valitsenud olukorrale, mis lõi soodsa pinnase näljahäda tekkeks. Selle asemel, et vaadelda näljahäda hetkelise kõrvalekaldumisena normaalsest olukorrast, on mõistetud, et näljahäda tekkepõhjused peitusid sügavamal tollastes oludes, mis muutsid ühiskonna haavatavaks. ${ }^{4}$ Näljaajaga seoses on arutletud ka võimu ja vastutuse piiride üle. On leitud, et võimude ebaõnnestunud hinnang olukorrale avaldas mõju kriisile tervikuna ja ka valitud abinõud sõltusid nii ideoloogilistest teguritest kui ka varem omaksvõetud toimimismudelitest. ${ }^{5}$ Soomes on 1860 . aastate näljahäda peetud pöördepunktiks, mil sai alguse põllumajanduse ratsionaliseerimine ja moderniseerimine. ${ }^{6}$

Erinevalt Soomest on Eestis 19. sajandi ühe suurima näljahäda uurimisega hakatud tegelema alles suhteliselt hiljuti. Tänuväärt tööd on siin teinud Kersti Lust, kes on teemat käsitlenud eri uurimustes ja avaldanud ka 19. sajandi näljahädadest põhjaliku eessõnaga varustatud allikapublikatsiooni.7 Tiit Rosenberg on eelkõige uurinud hädaabikomiteede tegevust näljahäda leevendamisel, ${ }^{8}$ Marten Seppel on käsitlenud näljahädasid

\footnotetext{
Voutilainen, Nälän vuodet. Nälänhätien historia (Helsinki: Atena, 2017); Tuomas Jussila, Lari Rantanen, "Nälällä on aina historiansa", Nälkävuodet 1867-1868, ed. by Tuomas Jussila, Lari Rantanen (Helsinki: Suomalaisen Kirjallisuuden Seura, 2018), 17-22.

4 Jussila, Rantanen, "Nälällä on aina historiansa", 16-17; Voutilainen, Poverty, Inequality and the Finnish 186os Famine, 58-62; Heli Huhtamaa, "Kewät kolkki, talwi tuima". Ilmasto, sää ja sadot nälkävuosien taustalla”, Nälkävuodet 1867-1868, ed. by Tuomas Jussila, Lari Rantanen (Helsinki: Suomalaisen Kirjallisuuden Seura, 2018), 57.

5 Vt Lari Rantanen, "“Silloin vilja on hopeaa”. Nälkävuodet, talouspolitiikka ja hallinnon toimeet”, Nälkävuodet 1867-1868, ed. by Tuomas Jussila, Lari Rantanen (Helsinki: Suomalaisen Kirjallisuuden Seura, 2018), 123-124.

6 Petri Rekonen, “"Suomen voi ei kelpaa kuin kärrynvoiteeksi”. Maatalouden käännekohta vai taanduma kehityksessä?”, Nälkävuodet 1867-1868, ed. by Tuomas Jussila, Lari Rantanen (Helsinki: Suomalaisen Kirjallisuuden Seura, 2018), 77-80.

7 Kersti Lust, "Kui suured näljahädad tabasid Eesti talurahvast 19. sajandil?", Tuna, 2 (2017), 139-145; Kersti Lust, "Näljaabist Peipsi rannaküladele 1868.-1869. aastal", Ajalooline Ajakiri, 4 (2008), 317-331; Kersti Lust, "Saaremaa 1868.-1869. aasta näljahäda regionaalsed ja sotsiaalsed aspektid", Sõnasse püütud minevik in honorem Enn Tarvel (Tallinn: 2009), 283-297; Kersti Lust, "Providing for the hungry? Famine relief in the Russian Baltic province of Estland, 1867-9", Social History, 40 (1) (2015), 15-37; Võitlus näljaga. 19. sajandi näljahädad Eesti külas. Dokumentide kogumik, koost Kersti Lust (Tartu: Rahvusarhiiv, 2015).

8 Tiit Rosenberg, "1867.-1869. aasta näljahäda ja hädaabikomiteede tegevus", Künnivaod (Tartu: Tartu Ülikooli Kirjastus, 2012), 337-343.
} 
pikemas ajaloolises perspektiivis, 17.-19. sajandil. ${ }^{9}$ Need teosed annavad põhjaliku ülevaate selle murrangulise perioodi kohta Eesti ajaloos. Palju tähelepanu on pööratud ka 19. sajandi põllumajandusele üldiselt. ${ }^{10} \mathrm{Külvi} \mathrm{ja}$ saagi suuruse küsimusega on aga tegeletud pigem vähe. Täpsemad andmed on avaldatud ainult kartuli mahapaneku ja saagi suuruse kohta Eesti- ja Liivimaal ajavahemikul $1838-64 .{ }^{11}$ Juhan Kahk on jälginud saagikuses toimunud muutusi 19. sajandi vältel. ${ }^{12}$ Kersti Lust on vaadelnud teraviljahindu ja saagikust, keskendudes muuhulgas 1860 . aastatele. ${ }^{13}$ Siinse uurimuse tulemused saagikuse kohta langevad hästi kokku Kersti Lusti andmetega.

Artikli eesmärk on esitada uusi teadmisi murranguliste 1860. aastate kohta, pöörates tähelepanu ühelt poolt saakide suurusele, teiselt poolt sellele, milliseid samme astusid vallad viljapuuduse leevendamiseks. Artikkel koosneb kahest osast. Esimeses osas on jälgitud põllumajanduse olukorda tollel aastakümnel, eelkõige peamisi viljeldavaid kultuure, et välja selgitada, kui palju kasvatati sel ajal Eestimaal ja Põhja-Liivimaal teravilja ja kartulit, milline oli saagi suurus inimese kohta ja kui suur oli saagikus. Samuti on esile toodud tegureid, mis muutsid põllumajanduse 1860. aastatel haavatavaks. Kui Eestis on seni uuritud eelkõige näljaabi andmist riiklikul tasandil või keskendutud hädaabikomiteede tegevusele, siis selle artikli teises osas on vaatluse alla võetud ka kohalik ehk valla tasand. Peatutud on Eestimaa ja Põhja-Liivimaa eri piirkondadel ja erilist rõhku on pandud abinõudele, millega püüti valdades leevendada toidupuudust ja tõrjuda näljahäda.

Kuna praegune Eesti ala oli jagatud kahe provintsi, Eestimaa ehk PõhjaEesti ja Liivimaa põhjaosa ehk Lõuna-Eesti vahel, siis on neid piirkondi enamasti vaadeldud eraldi. Liivimaa mandriosas on vaatluse alla võetud ainult eestlastega asustatud neli maakonda (Tartumaa, Võrumaa, Pärnumaa ja Viljandimaa) ehk Põhja-Liivimaa. Liivimaa koosseisu kuulus ka

\footnotetext{
9 Marten Seppel, Näljaabi Eesti- ja Liivimaal 17. sajandist 19. sajandi alguseni (Tartu: Tartu Ülikooli Kirjastus, 2008).

10 Tiit Rosenberg, "Põllumajanduse areng 19. sajandil ja 20. sajandi algul", Eesti ajalugu V. Pärisorjuse kaotamisest Vabadussõjani (Tartu: Ilmamaa, 2010), 110-129.

11 Eesti majandusajalugu I, koost Hendrik Sepp, Otto Liiv, Juhan Vasar (Tartu: Akadeemilise Kooperatiivi Kirjastus, 1937), 386-390.

12 Juhan Kahk, Peasant and lord in the process of transition from feodalism to capitalism in the Baltics (Tallinn: Eesti Raamat, 1982); Juhan Kahk, Die Krise der feudalen Landwirtschaft in Estland (Tallinn: Eesti Raamat, 1969); Juhan Kahk, "Uue põllumajanduse algus Eestis 1860-1880", Eesti Teaduste Akadeemia Toimetised, 43/2 (1994), 105-123.

13 Kersti Lust, “Teraviljahinnad Eesti kohalikel turgudel ja neid mõjutanud tegurid 1840-1900”, Ajalooline Ajakiri, 2 (2013), 217-245.
} 
Saaremaa, mida on artiklis kohati ka eraldi esile toodud, sest erinevalt Liivimaa mandriosast tabas seda piirkonda 1868. aasta näljahäda kõige rängemalt.

Saakide suuruse kindlakstegemisel on peamiseks allikaks olnud kindralkuberneride aruanded. Statistilised andmed talivilja (rukis), suvivilja (oder, kaer) ja kartuli külvi ja saakide suuruse (setvertides ${ }^{14}$ ) ning loomade arvu kohta sisalduvad Eesti- ja Liivimaa kindralkuberneri aastaaruannete lisades, ${ }^{15}$ kus on antud ka hinnang saagikuse kohta. Aruanded koostati Eestimaal adrakohtute ja Liivimaal sillakohtute esitatud andmete põhjal. Eestimaa kohta on sama tüüpi materjal säilinud ka Eestimaa Kubermangu Statistikakomitee arhiivis. ${ }^{16}$ Teated külvi ja saagi kohta võivad eri allikates lahkneda. Nii on väiksemaid erinevusi Eestimaa statistikakomitee ja Eestimaa kuberneri aruannetes ning ka adra- ja sillakohtute eri ametiasutustele esitatud andmetes. Saagi suurus esitati sageli ümardatult. Kõige suurema lüngana peab esile tõstma asjaolu, et Eestimaalt puuduvad täpsemad andmed 1868. aasta kohta. Neid ei leidu ka Eestimaa statistikakomitee materjalide hulgas ega kindralkuberneri aruannete mustandites. Sealsetest maakondadest on olemas ainult Maa-Virumaa ${ }^{17}$ andmed..$^{18}$

Kuberneri aruannetes esitatud külvi ja saakide absoluutarvude usaldusväärsust on pandud korduvalt kahtluse alla. Sulev Vahtre on rõhutanud, et kuberneride aruannetes keskvalitsusele esitatakse näiteks 1865. aasta olukorda tegelikust hoopis soodsamana, nimetades saaki keskmiseks või

\footnotetext{
14 Mahuühikuna 1 setvert $=8$ setverikku $=64$ karnitsat $=209,91$ liitrit; 1 setvert rukist $=147 \mathrm{~kg}, 1$ setvert otra $=123 \mathrm{~kg}$, 1 setvert kartuleid $=131 \mathrm{~kg}$.

15 Rahvusarhiiv (edaspidi RA), EAA.291.1.11366; 11479; 11602; 11616; 11708; 11725; 11866; 11867; 11924; 11934; 12094; 12095; 12189; 12190; 12221; 12307; 12362; 12466; 12472; 12636 : Eestimaa ja Liivimaa kuberneri aruanded 1860-70; RA, EAA.29.2.4744: Eestimaa kubermang 1868-77; RA, EAA.29.2.4758: Täiendused Eestimaa kubermangu aruandele 1869; RA, EAA.29.2.4759: Eestimaa kubermangu aruanne 1869; RA, EAA.29.2.4761: Eestimaa kubermangu aruanne 1870; RA, EAA.29.8.552a: Aruanne hindade ja maismaavedude kohta 1869; RA, EAA.29.10.125: Statistilised andmed Eestimaa kubermangu kohta 1866, 1867 ja 1869; RA, EAA.905.1.21: Eestimaa kuberneri ringkirjad; RA, EAA.296.4.2273: Liivimaa kuberneri 1861. aasta aruande mustand.

16 RA, EAA.41.1.41; 42; 43; 44; 46; 50; 53: Statistilised andmed Eestimaa kohta 1860-70.

17 Rakvere ehk Viru kreis jaotus 19. sajandil järgmiselt: Alutaguse, Ranna-Virumaa ja Maa-Virumaa. Maa-Virumaa alla kuulusid Viru-Jaagupi, Väike-Maarja ja Simuna kihelkonnad.

18 RA, EAA.902.1.1137: Ülevaade tali- ja suvivilja ning kartuli saagikusest; RA, EAA.29.8.21a: Lisad kubermangu aruande juurde 1868-69; RA, EAA.902.1.267: Andmed rahvastiku, saakide jm kohta; RA, EAA.902.1.1137: Andmed külvi ja saakide kohta 1843-74.
} 
isegi heaks. ${ }^{19}$ Kuberneride aruannete lisas toodud arvandmetest (vt tabel 3) on aga selgelt näha, et Eestimaal rukis ikaldus ja nii suvivilja- kui ka kartulisaak olid viletsad. Ka Liivimaal olid rukki- ja kartulisaak kehvad, ainult suviviljasaak oli veidi parem. Seega võib täheldada vastuolu kuberneri aruannete sõnastatud ülevaate lisadena esitatud arvandmete vahel, ent arvandmed on tekstist usaldusväärsemad. Juhan Kahk on kindlaks teinud, et kuberneride esitatud arvud on kooskõlas teistest allikatest pärit andmetega, kuid ta pidas absoluutarvude kasutamist riskantseks ning opereeris ainult suhtarvudega üldisemate tendentside väljaselgitamiseks. ${ }^{20} \mathrm{Ka} \mathrm{Kersti}$ Lust on pidanud usaldusväärsemaks andmeid saagikuse kohta, põhjendades seda muuhulgas allikakriitilise analüüsiga. ${ }^{21}$

Selles artiklis on parema puudusel siiski kasutatud kuberneride aruannete lisades esitatud absoluutarve, kuigi need ei pruugi täielikult vastata tegelikule olukorrale. Korrigeeritud on ainult üksikuid hooletusvigu. ${ }^{22}$ Absoluutarvud võimaldavad välja arvutada viljavaru umbkaudse suuruse inimese kohta. Selleks, et võrrelda Soome ja Eesti põllumajandustoodangut nälja-aastatel, ei piisa ainult suhtarvudest ja saagikuse kohta teadaolevast informatsioonist, vaja on ka andmeid külvi ja saagi suurusjärkude võrdlemiseks ning vilja sisseveo hindamiseks.

Tänu vallavalitsuste arhiividele on võimalik välja selgitada, kuidas eri piirkondades püüti leevendada ikalduse tagajärjel tekkinud puudust ja tagada kõigi vallaelanike varustamine viljaga. Vallavolikogu protokollid annavad pildi nii olukorra tõsiduse, magasivilja kasutamise kui ka vilja juurdeostmise vajaduse kohta. Paljud vallavalitsuste arhiivid on aja jooksul kaduma läinud, mistõttu on neid säilinud kokku 443 fondi ${ }^{23}$, seega on esindatud vähem kui pooled mõisate baasil loodud valdadest. Selliseid fonde, kus on protokolle 1868. ja 1869. aastast, on ainult 156, kuid ka kõigis neis ei ole säilinud volikogu protokolle, mille põhjal saab parima ülevaate

\footnotetext{
19 Sulev Vahtre, "Ilmastikuoludest Eestis XVIII ja XIX sajandil (kuni 187o. a.) ja nende mõjust põllumajandusele ning talurahva olukorrale", Eesti NSV ajaloo küsimusi VI. Tartu Riikliku Ülikooli Toimetised, vihik 258 (Tartu: Tartu Riiklik Ülikool, 1970), 130-131. 20 Kahk, Die Krise der feudalen Landwirtschaft in Estland, 239-243.

21 Lust, "Teraviljahinnad Eesti kohalikel turgudel ja neid mõjutanud tegurid 18401900", 221-222.

22 Viga on 1863. aasta Viljandi kreisi mõisa talumaa andmetes. Rukkisaagiks on märgitud 4997 setverti, mis vastab eelmises lahtris märgitud mahapandud kartulile, seega on kartuli kohta käiv arv mehhaaniliselt kantud edasi järgnevasse lahtrisse. Kuna on teada ka rukki saagikus (6 seemet), siis oli võimalik välja arvestada enam-vähem tegelikkusele vastav arv: 49470 setverti.

23 Arhiivijuht I. Riigi-, kohtu- ja omavalitsusasutused, koost Lea Leppik (Tartu: Eesti Ajalooarhiiv, 2003), 327-363.
} 
arutlusel olnud küsimustest ja vastuvõetud otsustest. Kahjuks puuduvad protokollid enamasti ka Saaremaalt.

Uurijad on rõhutanud, et saagi suurus sõltus ilmaoludest, kuid ühiskondlikud tegurid avaldasid mõju sellele, millised olid võimalused tulla toime saagi suuruse vaheldumisega. ${ }^{24}$ Tänase Eesti alal oli agraarsuhete kujundamisel riigi kõrval kõige olulisem osa mõisal. Mõisamajanduses viidi 1860. aastatel ellu suured muudatused, mis pidid kiirendama üleminekut teoorjuslikult majandamisviisilt rahamajandusele. Põldude laiendamine ja seni vähelevinud kultuuride (kartul, ristik) kasvatamine tõi kaasa ülemineku kolmeväljasüsteemilt mitmeväljasüsteemile. ${ }^{25}$ Suuremat tähelepanu hakati pöörama karjakasvatusele ja põldude väetamisele, kuid mõisate agrotehniline tase oli veel küllaltki madal. Nõudlus põllumajandustoodete järele oli aga suur, sest siseturul vajasid vilja kasvav linnarahvastik ja sõjavägi.

Talumajandus oli 1860. aastatel veel peaaegu täielikult sõltuv mõisamajandusest. Kui 1868. aastal teoorjus keelati, pidid talud muutunud tingimustes ümber orienteeruma. Taludele pakkus üleminek raharendile suuremat vabadust ja võimalust oma põlde ratsionaalsemalt harida. Raharendile oli 1867.-68. aastaks üle läinud 81\% Liivimaa taludest. ${ }^{26}$ Taludes kasutati kolmeväljasüsteemi, kus ühel kolmandikul põllumaal kasvas talivili ehk rukis, teisel suvivili ja kolmas oli kesas. Toidulaual oli kõige tähtsam teravili rukis. Suviviljadena kasvatati otra ja kaera, kusjuures oder kulus nii söögiks kui ka õllevalmistamiseks, kaer aga loomasöödaks. Üleminek rahamajandusele oli väga keeruline, sest isegi keskmise viljasaagiga aastatel ei tekkinud talurahval ülejääke, mida turustada. Viletsate saakide põhjuseks on peetud eelkõige kehva põllumajandusinventari ning maaharimise ja väetamise üldist madalat taset.

Eelmainitud põhjustele võib lisada ka vananenud maakasutussüsteemi kasutamise. Just nöörimaade ja ribapõldude süsteem ei võimaldanud taludel üle minna viljavaheldusele ega kasutusele võtta eesrindlikumaid põlluharimisviise..$^{27}$ Eestimaal hariti 1867. aastal 90\% talupoegade põldudest kahe- või kolmeväljasüsteemi alusel ja ainult 10\% mitmepõllusüsteemi alusel, samal ajal kui mõisates olid vastavad näitajad $24 \%$ ja $76 \%{ }^{28}$ Kolme-

\footnotetext{
24 Vahtre, "Ilmastikuoludest Eestis XVIII ja XIX sajandil", 145-150.

25 Rosenberg, "Põllumajanduse areng", 114.

26 Kahk, "Uue põllumajanduse algus Eestis 186o-188o", 115-117.

27 Hans Kruus, Eesti ajaloo lugemik III. Valitud lugemispalad Eesti ajaloo alalt XVII ja XIX sajandil (Tartu: Eesti Kirjanduse Selts, 1929), 230.

28 Paul Jordan, Beiträge zur Statistik des Gouvernements Ehstland. Zweiter band (Reval: Lindfors' Erben, 1871), 59.
} 
väljasüsteem püsis Eesti- ja Saaremaa ribapõldudega kompaktsetes külades kuni talude kruntimõõtmiseni, mis tavaliselt viidi läbi vahetult enne talude müükipanekut mõisa poolt. Seoses talude päriseksostmisega hakkas 1850. aastatest Põhja-Liivimaal (v.a Saaremaa) ja 1870. aastatest ka Eestimaal mõisnike suurmaavalduse kõrvale tekkima talupoeglik väikemaavaldus. ${ }^{29}$ Põhja-Liivimaal toimus talude päriseksostmine varakult just neis valdavalt hajaasustusega piirkondades, kus taludel oli kogunenud lina müügist raha ja kus ei olnud vaja läbi viia kruntimõõtmist enne talude müügiga alustamist. ${ }^{30}$ Samal ajal tõi just see kaasa Liivimaa kiirema kaubanduslikrahandusliku arengu võrreldes Eestimaaga.

\section{Saagid ja saagikus}

Kõige tähtsam teravili rukis talus viletsaid kasvutingimusi paremini, mistõttu rukki saagikust mõjutasid siinsed ilmastikuolud vähem kui suvivilja ja kartuli saagikust. Eestimaal ja Põhja-Liivimaal kokku oli taliviljakülv 1860. aastatel ligikaudu 200 ooo setverti ja talivilja saak ületas parimatel aastatel 1000 ooo setverdi piiri (vt tableid 1 ja 2). 1860. aastate keskmine talivilja saagikus (1868. aastat arvestamata) oli 4,8 seemet. Talivilja saak oli vilets juba 1865 . aastal, mil see jäi alla 700 ooo setverdi ja ka 1867. aastal ei olnud saak kuigivõrd parem. Nendel aastatel oli Eestimaal ja PõhjaLiivimaal tervikuna rukki saagikus vastavalt 3,3 ja 3,7 seemet, kuid Eestimaal oli juba 1865. aastal ikaldus (saagikus 2,6 seemet) ja ka 1867. aastal oli saagikus väga vilets (3,1 seemet). Erinevalt Eestimaast ei vähenenud Põhja-Liivimaal rukki saagikus kümnendi vältel kordagi ikalduse tasemele, isegi mitte 1868. aastal, mil saagikus oli vilets (3,9 seemet). Eestimaalt on 1868. aasta kohta olemas ainult Maa-Virumaa andmed: sealne saagikus (3,2 seemet) oli madalam kui Liivimaa põhjaosas. Olukord hakkas paranema 1869.-70. aastal, mil hoolimata sellest, et rukkikülv jäi väiksemaks kui enne näljaaega, ulatus saak tänu keskmisele saagikusele (5,2-5,3 seemet) ligi 1000 ooo setverdini. Rukki saagikus oli nendel aastatel Eestimaal isegi veidi parem (5,4-5,6 seemet) kui Liivimaa põhjaosas.

\footnotetext{
29 Jordan, Beiträge zur Statistik des Gouvernements Ehstland. Zweiter band, 54-55; Kahk, "Uue põllumajanduse algus Eestis 1860-1880", 114-115; Juhan Kahk, Talude päriseksostmise aegu (Tallinn: Eesti Teaduste Akadeemia, 1993), 67; Mati Laur, "Väikemaaomandi teke", Eesti ajalugu V. Pärisorjuse kaotamisest Vabadussõjani (Tartu: Ilmamaa, 2010), 104-109.

30 Mati Laur, Kersti Lust, Priit Pirsko, Ülle Tarkiainen, Talude päriseksostmine Pärnumaa andmestiku põhjal (Tartu: Eesti Ajalooarhiiv, 2014), 61-78.
} 
Tabel 1. Külv ja saak Eestimaal 186o. aastatel (setvertides) ${ }^{31}$

\begin{tabular}{|l|r|r|r|r|r|r|}
\hline & $\begin{array}{c}\text { Talivilja- } \\
\text { külv }\end{array}$ & $\begin{array}{c}\text { Talivilja- } \\
\text { saak }\end{array}$ & $\begin{array}{c}\text { Suvivilja- } \\
\text { külv }\end{array}$ & $\begin{array}{c}\text { Suvivilja- } \\
\text { saak }\end{array}$ & $\begin{array}{c}\text { Kartuli- } \\
\text { panek }\end{array}$ & $\begin{array}{c}\text { Kartuli- } \\
\text { saak }\end{array}$ \\
\hline 1860 & 93551 & 466679 & 119157 & 463351 & 141426 & 435985 \\
\hline 1861 & 87646 & 340687 & 123750 & 482160 & 118963 & 452514 \\
\hline 1862 & 94822 & 535078 & 119248 & 637646 & 121956 & 334927 \\
\hline 1863 & 95368 & 477398 & 123226 & 678039 & 115150 & 544266 \\
\hline 1864 & 92876 & 419909 & 121260 & 497059 & 112402 & 374640 \\
\hline 1865 & 90653 & 238880 & 124363 & 456472 & 113758 & 372565 \\
\hline 1866 & 87799 & 448915 & 113993 & 596232 & 107265 & 295825 \\
\hline 1867 & 87800 & 271908 & 115555 & 391904 & 106529 & 297792 \\
\hline 1868 & & & & & & \\
\hline 1869 & 89434 & 481408 & 116631 & 652297 & 109998 & 593795 \\
\hline 1870 & 92323 & 515546 & 117778 & 574284 & 118742 & 662269 \\
\hline $\begin{array}{l}\text { Kesk- } \\
\text { mine }\end{array}$ & 91227,2 & 419640,8 & 119496,1 & 542944,4 & 116618,9 & 436457,8 \\
\hline
\end{tabular}

Suviviljana kasvatati peamiselt otra ja kaera, kusjuures kaer läks eelkõige loomasöödaks. Eesti alal tervikuna jäi suvivilja külv enamasti $255000-265000$ setverdi piiridesse. Saak seevastu kõikus üsna palju, jäädes vahemikku 1080 oooo - 1600 ooo setverti. Suvivilja saagikus oli kõrgem Põhja-Liivimaal, jäädes vahemikku 4,2-6,5 seemet, samal ajal kui Eestimaal oli see vahemikus 3,4-5,6 seemet. 1868. aastal suvivili PõhjaLiivimaal ikaldus, saagikus oli ainult 2,9 seemet, mille tulemusel saak vähenes kõige paremate aastatega võrreldes poole võrra. Suvivili ikaldus ka Eestimaal, Maa-Virumaal oli saagikus ainult 2,4 seemet. 1869. aastal kasvas suvivili hästi, saagikus oli küll keskmine, kuid saavutas Eestimaal selle aastakümne kõige kõrgema taseme (5,6 seemet). Nii nagu rukki korral, oli ka suvivilja saagikus 1869.-70. aastal Eestimaal isegi veidi kõrgem kui Liivimaa põhjaosas.

31 Tabel põhineb Eestimaa kuberneri aruannete lisades esitatud andmetel: RA, EAA.291.1.11366; 11479; 11616; 11725; 11867; 11934; 12095; 12190; 12472. 
Tabel 2. Külv ja saak Põhja-Liivimaal 186o. aastatel (setvertides) ${ }^{32}$

\begin{tabular}{|l|r|r|r|r|r|r|}
\hline & $\begin{array}{c}\text { Talivilja- } \\
\text { külv }\end{array}$ & $\begin{array}{c}\text { Talivilja- } \\
\text { saak }\end{array}$ & $\begin{array}{c}\text { Suvivilja- } \\
\text { külv }\end{array}$ & $\begin{array}{c}\text { Suvivilja- } \\
\text { saak }\end{array}$ & $\begin{array}{c}\text { Kartuli- } \\
\text { panek }\end{array}$ & \multicolumn{1}{c|}{$\begin{array}{c}\text { Kartuli- } \\
\text { saak }\end{array}$} \\
\hline $\mathbf{1 8 6 0}$ & 106405 & 563957 & 137302 & 623490 & 104255 & 443912 \\
\hline $\mathbf{1 8 6 1}$ & 106092 & 465346 & 140396 & 695975 & 93738 & 482349 \\
\hline $\mathbf{1 8 6 2}$ & 108271 & 598298 & 139285 & 825813 & 92576 & 459128 \\
\hline $\mathbf{1 8 6 3}$ & 109439 & 607713 & 143280 & 925125 & 91195 & 461434 \\
\hline $\mathbf{1 8 6 4}$ & 107232 & 663553 & 141496 & 797664 & 94035 & 383386 \\
\hline $\mathbf{1 8 6 5}$ & 108034 & 424158 & 142743 & 758016 & 95863 & 376253 \\
\hline $\mathbf{1 8 6 6}$ & 109767 & 596697 & 141154 & 937211 & 93461 & 364578 \\
\hline $\mathbf{1 8 6 7}$ & 110574 & 464378 & 142601 & 717902 & 95289 & 386897 \\
\hline $\mathbf{1 8 6 8}$ & 110183 & 433408 & 145101 & 424575 & 92222 & 309136 \\
\hline $\mathbf{1 8 6 9}$ & 97424 & 498056 & 144286 & 742186 & 102983 & 443609 \\
\hline $\mathbf{1 8 7 0}$ & 92592 & 456080 & 137239 & 570289 & 100229 & 518064 \\
\hline $\begin{array}{l}\text { Kesk- } \\
\text { mine }\end{array}$ & 106001,2 & 524694,9 & 141353 & 728931,5 & 95986 & 420795,1 \\
\hline
\end{tabular}

Kartulikasvatus hakkas Baltikumis laiemalt levima alles 1830. aastatel, kusjuures seda kasutati eelkõige viinavabrikutes, kuna see oli odavam tooraine kui rukis. Lisaks kasutati kartulit ka tärklisetööstuses. Kartulit pandi 1860. aastatel tervel Eesti alal maha üle 200 ooo setverdi. Erinevalt teraviljast kasvatati Liivimaa põhjaosas kartulit tunduvalt vähem kui Eestimaal: Eestimaal pandi kartulit maha keskmiselt $20 \%$ võrra rohkem kui Põhja-Liivimaal, kuid saagi suurus ei olnud kuigi erinev, sest Eestimaal oli kartuli saagikus viletsam kui Liivimaa põhjaosas. Ikaldused olid sagedased, Eestimaal ikaldus kartuli saak nii 1862., 1866. kui ka 1867. aastal, saagikus oli eelmainitud kahel viimasel aastal ainult 2,8 seemet. Sama suur oli kartuli saagikus ka 1868. aastal Maa-Virumaal. Põhja-Liivimaal tervikuna sel aastal saak siiski ei ikaldunud, kuid oli vilets (saagikus 3,4 seemet). Näljaajast taastumisele aitas kaasa rekordiline kartulisaak Eestimaal nii 1869. kui ka 1870. aastal, mil see ületas 662 ooo setverdi piiri. Eestimaal ja Põhja-Liivimaal kokku ulatus kartulisaak üle 1 ooo ooo setverdi (1869. aastal 1037 404 ja 1870. aastal 1180333 setverti), mis oli märkimisväärselt suurem kui varasematel aastatel. Saagikus oli Eestimaal nendel aastatel küll keskmine

32 Tabeli koostamisel on tuginetud Liivimaa kuberneride aruannete lisadele: RA, EAA.291.1.11602; 11708; 11866; 11924; 12094; 12189; 12221; 12307; 12466; 12636; RA, EAA.296.4.2273: Liivimaa Kuberneri 1861. aasta aruande mustand. 
(5,4-5,6 seemet), kuid isegi veidi parem kui samal ajal Liivimaa põhjaosas (vastavalt 4,3 ja 5,2 seemet).

Kokkuvõtlikult võib väita, et kui Eesti alal püsis tali- ja suvivilja külvi suurus aastatel 1860-67 enam-vähem samal tasemel, siis mahapandud kartuli hulk veidi kahanes. 186o. aastatel ei olnud ühtegi hea (7-8 seemet) või väga hea ( 9 ja rohkem seemet) saagikusega aastat, peamiselt oli saagikus kas vilets (3-4 seemet) või keskmine ( $5-6$ seemet). ${ }^{33} \mathrm{Ka}$ enne näljaaega oli ainult üksikutel aastatel saagikus keskmine, enamasti oli see vilets või isegi ikaldus. Kogu käsitletud ala ulatuses jäi talivilja saagikus 186o. aastatel vahemikku 3,3-5,6 seemet. Suvivilja saagikus oli talivilja omast veidi parem, jäädes vahemikku 4,2-6 seemet. Kartuli saagikus oli 3,3-5,4 seemet. Peamise toiduteravilja rukki puudus tekkis juba siis, kui lõikus andis 3-4 seemet, suvivilja puudusele osutab saagikuse kahanemine 3 seemnele. Kui aga kartul andis 3 seemet, tulid talupojad siiski enam-vähem toime.

Tabel 3. Saagikus Eestimaal ja Põhja-Liivimaal

\begin{tabular}{|l|r|r|r|r|r|r|}
\hline \multirow{2}{*}{ Aasta } & \multicolumn{2}{|c|}{ Rukis } & \multicolumn{2}{|c|}{ Oder } & \multicolumn{2}{|c|}{ Kartul } \\
\cline { 2 - 7 } & Eestimaa & Liivimaa & Eestimaa & Liivimaa & Eestimaa & Liivimaa \\
\hline 1860 & 5 & 5,3 & 3,9 & 4,5 & 3,1 & 4,3 \\
\hline 1861 & 3,9 & 4,4 & 3,9 & 5,0 & 3,8 & 5,1 \\
\hline 1862 & 5,6 & 5,5 & 5,3 & 5,9 & 2,7 & 5,0 \\
\hline 1863 & 5 & 5,6 & 5,5 & 6,5 & 4,7 & 5,1 \\
\hline 1864 & 4,5 & 6,2 & 4,1 & 5,6 & 3,3 & 4,1 \\
\hline 1865 & 2,6 & 3,9 & 3,7 & 5,3 & 3,3 & 3,9 \\
\hline 1866 & 5,1 & 5,4 & 5,2 & 6,6 & 2,8 & 3,9 \\
\hline 1867 & 3,1 & 4,2 & 3,4 & 5,0 & 2,8 & 4,1 \\
\hline 1868 & & 3,9 & & 2,9 & & 3,4 \\
\hline 1869 & 5,4 & 5,1 & 5,6 & 5,1 & 5,4 & 4,3 \\
\hline 1870 & 5,6 & 4,9 & 4,9 & 4,2 & 5,6 & 5,2 \\
\hline $\begin{array}{l}\text { Kesk- } \\
\text { mine }\end{array}$ & 4,6 & 5,1 & 4,5 & 5,4 & 3,7 & 4,5 \\
\hline
\end{tabular}

Ikaldus (saagikus alla 3 seemne) puudutas üldjuhul ainult ühte põllumajanduskultuuri ja oli enamasti piirkondlik. Nii oli näiteks 1862. aastal talija suvivilja saak keskmine, kuid Eestimaal ikaldus kartul. 1865. aastal oli ilmastik ebaharilikult muutlik, mistõttu olid saagid viletsad ja Põhja-Eestis

33 Vahtre, "Ilmastikuoludest Eestis XVIII ja XIX sajandil", 147-148. 
ikaldus talivili. ${ }^{34}$ Teravilja saak suurenes 1866 . aastal, ent vähenes uuesti 1867. aastal, Eestimaal ikaldus kartul aga juba teist aastat järjest. Eestimaal ja Põhja-Liivimaal, eelkõige Saaremaal, järgnes viletsate saakidega 1865. ja 1867. aastale 1868. aasta vihmane suvi, mis tõi kaasa ikalduse ja mitmel pool ka näljahäda. Saaremaal oli olukord kõige keerulisem, sest maapind oli väheviljakas. Taliviljast saadi seal 2, suviviljast 2,5 ja kartulist 0,5 seemet, seega kartulit saadi seal vähem, kui maha pandi. Põhja-Liivimaal vähenes 1868. aastal kõige märgatavamalt suviviljasaak, kuid ka talivilja ja kartuli saagikus oli vilets. Teravilja saadi sel aastal 1860. aastate keskmisest ainult $68 \%$ ja kartulit $73 \%$.

Põldude viletsa saagikuse üks põhjuseid oli nõrk väetamine. Väetisena kasutati sõnnikut, mille hulk sõltus peetud loomade arvust, karjakasvatust ei peetud 1860. aastatel põlluharimise kõrval aga oluliseks. Loomapidamise peamiseks põhjuseks oli vajadus tööloomade järele, mitte niivõrd huvi karjakasvatussaaduste vastu. Põhja-Liivimaal oli 1866. aastal aia- ja põllumaa tiinu kohta 1,2 suurt sarvlooma ja 1,2 väikelooma. ${ }^{35}$ Sarvloomade arv vähenes aastatel 1869-70 loomahaiguste leviku tõttu, kuid nende üldarv jäi siiski suuremaks kui 1860. aastate alguses.

Eestimaa jäi üldise saagikuse poolest Põhja-Liivimaast maha (vt tabel 3 ). Keskmine rukki saagikus oli Lõuna-Eestis 10\% võrra, suvivilja ja kartuli saagikus aga isegi $20 \%$ võrra suurem kui Põhja-Eestis. Veidi erandlik oli olukord 1869.-70. aastal, mil saagikus Eestimaal oli veidi suurem kui Liivimaa põhjaosas: Eestimaal saadi 1869. aastal taliviljast 5,4, suviviljast 5,6 ja kartulist 5,4 seemet, sealjuures olid Põhja-Liivimaal kõik näitajad viletsamad (vastavalt 5,1, 5,1 ja 4,3 seemet).

Tabel 4. Saak elaniku kohta 186o. aastatel Eestimaal ja Põhja-Liivimaal (setvertides) ${ }^{36}$

\begin{tabular}{|l|r|r|r|r|r|r|}
\hline \multirow{2}{*}{ Aasta } & \multicolumn{2}{|c|}{ Rukis } & \multicolumn{2}{c|}{ Suvivili } & \multicolumn{2}{c|}{ Kartul } \\
\cline { 2 - 7 } & Eestimaa & Liivimaa & Eestimaa & Liivimaa & Eestimaa & Liivimaa \\
\hline 1860 & 1,5 & 1,3 & 1,5 & 1,4 & 1,4 & 1,0 \\
\hline 1861 & 1,1 & 1,0 & 1,5 & 1,5 & 1,4 & 1,1 \\
\hline 1862 & 1,7 & 1,3 & 2,0 & 1,8 & 1,1 & 1,0 \\
\hline 1863 & 1,5 & 1,3 & 2,2 & 2,0 & 1,7 & 1,0 \\
\hline 1864 & 1,3 & 1,4 & 1,6 & 1,6 & 1,2 & 0,8 \\
\hline
\end{tabular}

\footnotetext{
34 Vahtre, "Ilmastikuoludest Eestis XVIII ja XIX sajandil”, 130-131.

35 RA, EAA.291.1.12094: Liivimaa kuberneri aruanne 1866. aasta kohta.

36 Elanike arv on pärit Eestimaa ja Liivimaa kuberneri aruannete lisades esitatud andmetest.
} 


\begin{tabular}{|l|r|r|r|r|r|r|}
\hline \multirow{2}{*}{ Aasta } & \multicolumn{2}{|c|}{ Rukis } & \multicolumn{2}{c|}{ Suvivili } & \multicolumn{2}{c|}{ Kartul } \\
\cline { 2 - 7 } & Eestimaa & Liivimaa & Eestimaa & Liivimaa & Eestimaa & Liivimaa \\
\hline 1865 & 0,8 & 0,9 & 1,4 & 1,6 & 1,2 & 0,8 \\
\hline 1866 & 1,4 & 1,2 & 1,9 & 2,0 & 0,9 & 0,8 \\
\hline 1867 & 0,8 & 0,9 & 1,2 & 1,5 & 0,9 & 0,8 \\
\hline 1868 & & 0,9 & & 0,9 & & 0,6 \\
\hline 1869 & 1,5 & 1,0 & 2,1 & 1,5 & 1,9 & 0,9 \\
\hline 1870 & 1,6 & 0,9 & 1,8 & 1,1 & 2,0 & 1,0 \\
\hline
\end{tabular}

Põlluviljakus oli väga kõikuv ja maakondade vahel võib täheldada suuri erinevusi. Eri valdades ja isegi külades võis saagikus oluliselt erineda nii mikroklimaatiliste tingimuste kui ka mullastiku eripära tõttu. Tartumaa oli Põhja-Liivimaa ainus piirkond, kus 1860. aastatel peaaegu pidevalt saadi keskmist ja isegi head saaki. Seevastu Pärnu- ja Viljandimaal oli suurem osa selle kümnendi aastatest kas viletsa või keskmise saagiga. Saaremaa põllud andsid veel 19. sajandi keskpaiku üsna häid saake, sest neile sobisid ka primitiivsemad tööriistad, kuid viletsa väetamise tingimustes viis see maa väljakurnamiseni. Saaremaa hakkas saagikuse poolest teistest maakondadest selgelt maha jääma juba 1860. aastatel, sest sealsetel õhukestel muldadel ei olnud võimalik teha sügavamat kündi, samal ajal kui näiteks Viljandimaa põldudele mõjus see hästi ja tõi kaasa saagikuse tunduva kasvu. ${ }^{37}$

Ikalduse tagajärjel olid 1868. aastal saagid mitmetes Eestimaa ja PõhjaLiivimaa piirkondades ning eriti Saaremaal nii väikesed, et need ei võimaldanud ületalve elada ega vilja uueks külviks säästa. Kriis jõudiski haripunkti 1868. aasta talvel ja 1869. aasta kevadel, mil näljahäda tabas kõige mahajäänumaid piirkondi, haarates Eestimaa kubermangu enam-vähem tervikuna; kõige halvem oli olukord Läänemaal. Liivimaa põhjaosa maakondadest puudutas see rängalt vaid Saaremaad. ${ }^{38}$ Näljaga kaasnesid epideemiad, eelkõige tüüfus, millele lisandusid düsenteeria, leetrid, rõuged jne. ${ }^{39}$

Eestimaal ja Põhja-Liivimaal kasvanud vili kasutati enamasti ära siseturul. Vilja vajati linnades, kus tol ajal elas alla 10\% rahvastikust. Mõisad kasvatasidki vilja eelkõige turu tarbeid silmas pidades, talud pidid hoolitsema oma vajaduste katmise eest. Maaelanikest moodustasid enamiku talupojad,

37 Kahk, Peasant and lord in the process of transition from feodalism to capitalism in the Baltics, 113-116.

38 Kersti Lust, "19. sajandi näljahädad Eestis", Võitlus näljaga. 19. sajandi näljahädad Eesti külas. Dokumentide kogumik, koost Kersti Lust (Tartu: Rahvusarhiiv, 2015), 41.

39 Vahtre, "Ilmastikuoludest Eestis XVIII ja XIX sajandil", 136-137. 


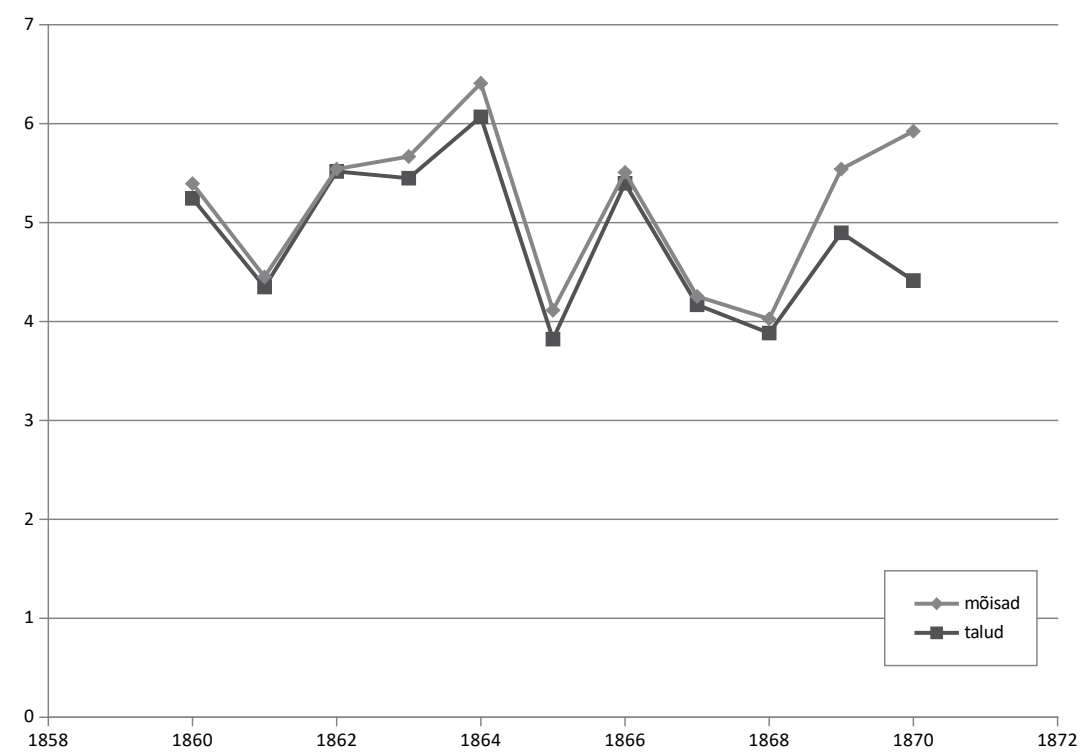

Skeem 1. Rukki saagikus Põhja-Liivimaa mõisa- ja talumaal 1860-70

kellest valdav osa elas talumaal, nendele lisandusid veel mõisamaal elavad talupojad. ${ }^{40}$ Maaelanike hulka on loetud ka mõisnikud ja mõisaametnikud ning muud maal elavad ametimehed, kuid nende osakaal oli väga väike. ${ }^{41}$ Inimese aastaseks toiduvajaduseks peeti sel ajal üks setvert talivilja ja $2 / 3$ setverti suvivilja (kokku umbes $210 \mathrm{~kg}$ ). Kaasaegsete tähelepanekute põhjal oli see norm veidi suurem. Juhan Kahk on arvestanud inimese aastaseks vajaduseks 1 setvert tali- ja 1 setvert suvivilja. ${ }^{42}$ Eestimaal saadi elaniku ${ }^{43}$ kohta 1860. aastatel keskmiselt 1,1-1,7 setverti rukist ja 1,2-2,2 setverti suvivilja (vt tabel 4). Rukkisaak inimese kohta oli o,8 setverti nii 1865. kui ka 1867. aastal ning kaudsetel andmetel veelgi vähem 1868. aastal, mil see jäi samuti normist allapoole. Põhja-Liivimaal saadi 1860. aastatel elaniku kohta rukist keskmiselt 1-1,4 setverti ja suvivilja 1,1-2 setverti. Rukkisaak oli veidi alla normi (keskmiselt o,9 setverti inimese kohta) 1865., 1867., 1868. ja 1870. aastal. 1868. aastal jäi ka suviviljasaak normist allapoole (o,9 setverti).

\footnotetext{
$40 \quad$ RA, EAA.41.1.33, 1. 25: Eestimaa rahvastik 1854-92.

$41 \quad$ Ibid., 1. 7.

42 Juhan Kahk, Murrangulised neljakümnendad (Tallinn: Eesti Raamat, 1978), 113-114.

43 Elanike arv on pärit Eestimaa ja Liivimaa kuberneri aruannete lisades esitatud andmetest.
} 


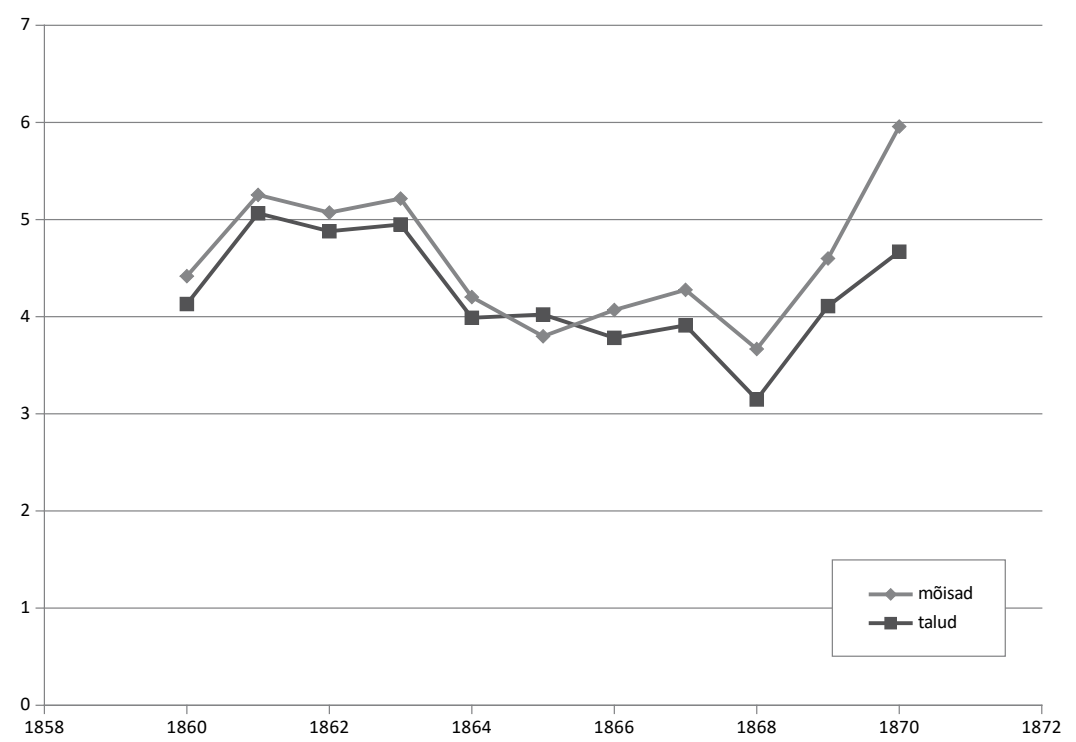

Skeem 2. Kartuli saagikus Põhja-Liivimaa mõisa- ja talumaal 1860-70

Olukord oli kõige parem Tartu- ja Võrumaal (1,1-1,2 setverti rukist inimese kohta), seevastu Viljandimaal ning Pärnumaal saadi vilja inimese kohta alla normi. Saaremaal oli olukord kõige kehvem: 1868. aastal oli seal rukki kogusaak (nii mõisa- kui ka talupõldudelt) ainult o,6 setverti inimese kohta. Eestimaal oli saak inimese kohta vaid üksikutel aastatel parem kui PõhjaLiivimaal. Kuigi saagikus oli Põhja-Liivimaal suurem, põhjustas madalamat näitajat inimese kohta vähese külvipinnaga väikekohtade suur arv kroonumõisates, kus tähtsal kohal olid kõrvalelatusalad, eelkõige kalapüük. Ka 1868. aastal olid nii rukki- kui ka kartulisaak inimese kohta kõige väiksemad Pärnu- ja Saaremaal, kus oli eriti suur kroonumõisate osakaal.

Mõisate ja talude vahel pole teravilja ja kartuli saagikuses kuni aastateni 1869-70 väga suuri erinevusi täheldada. Näiteks oli Liivimaa põhjaosas rukki saagikus 1864. aastal mõisates 6,4 ja taludes 6 seemet, kuid 1868. aasta ikaldus tabas nii mõisaid kui ka talusid enam-vähem samal moel. Kui kartuli saagikus oli 1865. aastal mõisapõldudel isegi madalam kui talupõldudel, saabus kõige sügavam madalseis talupõldudel 1868. aastal (mõisates 3,7 ja taludel 3,1 seemet). Seejuures on oluline silmas pidada, et kroonu- ja eramõisate mõisapõldude saagikuses olulisi erinevusi ei olnud. Rasketest 
aegadest taastumine toimus mõisates kiiremini kui taludes: mõisapõldude saak oli aastatel $1869-70$ talupõldudest $20 \%$ võrra suurem. Just 1860. aastate lõpuga sai alguse saagikuse tunduv paranemine mõisates võrreldes taludega, kusjuures nagu Soomeski võib ka Eestis näljaaega pidada omalaadseks veelahkmeks.

Kui veel 1860. aastatel suutsid talupõllud saagikuse poolest mõisapõldudega võistelda, siis 1870. aastatel hakkasid mõisapõldude saagid majanduse ümberkorralduste tõttu paranema. Mõisates oli alanud üleminek parandatud kolmeväljasüsteemilt kuue- ja seitsmeväljasüsteemile. Põlluviljakuse kiiremat tõusu mõisates ongi seletatud ajakohasema viljavaheldussüsteemi, loomakasvatuse intensiivistamise, parema väetamise ning agrotehnika kasutamisega. ${ }^{44} \mathrm{Ka}$ võimaldas sügavam künd hõlmadraga tõsta kultuuride saagikust.

Mõisad said oma sissetuleku eelkõige viljamüügist ja viinapõletamisest. Veel 186o. aastate alguses veeti nii Liivi- kui ka Eestimaalt välja arvestatav kogus vilja. Väljavedu toimus Liivimaal eelkõige Riia, vähesel määral ka Pärnu ja Kuressaare sadamate kaudu. Riia kaudu veetava vilja seas moodustas Liivimaalt pärit vili suhteliselt väikese osa, enamasti oli see pärit hoopis Venemaalt, Kuramaalt, Poolast ja mujalt (1867. aastal kokku 532005 setverti). Pärnu ja Kuressaare kaudu veeti 1867. aastal välja vastavalt 42731 ja 17508 setverti, kusjuures Saaremaalt (Kuressaarest) väljaveetud vili moodustas $12 \%$ seal kasvatatud teraviljast. ${ }^{45} 1868$. aastal Liivimaal vilja väljavedamiseks ei olnud. ${ }^{46}$ Eestimaa kõige tähtsamast sadamast Tallinnast veeti vilja välja siiski ka 1868.-69. aastal, kuigi selle kogus oli väga väike (vastavalt 6148 ja 3150 setverti). ${ }^{47}$ Veel 1860. aastal oli Tallinna sadamast välja veetud $8 \%$ Eestimaal toodetud taliviljast ja 10,6\% suviviljast, kusjuures viimasest moodustasid enamiku oder ja kaer, nisu osa oli seevastu vähene. ${ }^{48}$ Eestimaale toodi Vene sadamatest sisse rukist, nisu ja kaera, kuid andmed sisseveo kohta on üsna ebatäpsed. Otsest viljapuudust Eesti- ja Liivimaal ei tekkinud: raha olemasolul oli vilja võimalik juurde osta, kuid selle hind oli kõrge.

\footnotetext{
44 Väino Sirk, "Põllumajanduslik mõte ja põllumajanduslik kirjandus Eestis 19. sajandi keskpaigast 1917. aastani”, Eesti Teaduste Akadeemia Toimetised, 43/2 (1994), 187188; Kahk, Die Krise der feudalen Landwirtschaft in Estland, 200-202; Kahk, "Uue põllumajanduse algus Eestis 1860-1880", 116-117; Rosenberg, "Põllumajanduse areng", 115.

45 RA, EAA.291.1.12189: Liivimaa kuberneri aruanne 1867. aasta kohta.

46 RA, EAA.291.1.12307: Liivimaa kindralkuberneri aruanne 1868. aasta kohta.

47 RA, EAA.291.1.12472: Eestimaa kuberneri aruanne 1869. aasta kohta; RA, EAA.291.2.4759: Eestimaa kubermangu olukorrast 1869.

48 RA, EAA.291.1.11366: Eestimaa kuberneri aruanne 1860. aasta kohta.
} 
Viina oli varem nii Eesti- kui ka Liivimaal toodetud eelkõige teraviljast, kuid kartulikasvatuse laienedes alates 1830. aastatest hakati seda üha enam tootma ka kartulist. ${ }^{49} 19$. sajandi keskpaiku pandi Eestimaa mõisates kartulit maha ligi kaks korda rohkem kui taludes, mistõttu valmis seal ka suurem osa viinatoodangust kartulist. Liivimaal seevastu kasvatati mõisates vähem kartuleid kui taludes, mistõttu oli selle osakaal väiksem ka viinatoodangus..$^{50}$ Täiesti uus olukord kujunes Balti kubermangude mõisate viinatööstuses, kui Vene riigis viidi 1863. aastal sisse aktsiisisüsteem, mille tulemusel kujunes kogu riigi ulatuses piirituse vabaturg. Paljude mõisate viinaköögid lõpetasid tegevuse, mistõttu viinavabrikute arv hakkas järsult kahanema. Kui veel 1861. aastal oli Liivimaa põhjaosas 244 viinavabrikut, siis 1868 . aastal oli neid ainult $91 .{ }^{51}$ Eestimaal läks 1869. aastal tehtud arvestuste kohaselt viinavabrikutesse rohkem kui kolmandik kartulisaagist. Kuigi ka seal vähenes aastatel 1864-70 mõisate viinaköökide arv 146-lt 105-le, jäi kogutoodang enam-vähem endisele tasemele. ${ }^{52} \mathrm{Kui}$ 186o. aastaid iseloomustas veel tootmise langus, siis uute seadmete hankimine, tootmistehnika areng ning tootmise kontsentreerumine viinavabrikutesse tõid 1870. aastatest alates kaasa kiire tõusu. ${ }^{53}$ Viinatööstus muutus eelkõige Põhja-Eestis oluliseks turuks ka taludele, kui kartul hakkas pärast näljaaega jõudma üha suuremas ulatuses ka talurahva toidulauale.

\section{Valdade abinõud viljapuuduse leevendamiseks}

Ikalduse ja viljapuuduse tingimustes oli vaja võtta kasutusele abinõud, et vältida toidupuudust ja kindlustada seemnevilja olemasolu. Riiklik näljaabi seisnes 1868.-69. aastal peamiselt otseses rahalaenus, kusjuures Eestimaa sai riigilt toetuslaenu kokku 210 ooo, Mandri-Liivimaa 50 ooo ja Saaremaa 150 ooo rubla..$^{54}$ Ostujõudu kahandas tõsiasi, et ikalduse tõttu tõusid viljahinnad erakordselt kõrgele. ${ }^{55}$ Olukorras, kus riik ootas rahvalt eelkõige ise

49 Otu Ibius, Ühe tööstusharu ajaloost (Tallinn: Eesti Raamat, 1977), 72.

50 Rosenberg, "Põllumajanduse areng", 112-113.

51 RA, EAA.296.4.2273: Liivimaa kuberneri 1861. aasta aruande mustand; RA, EAA.291.1.12307: Liivimaa kuberneri aruanne 1868. aasta kohta.

52 Kahk, "Uue põllumajanduse algus Eestis 1860-1880", 107.

53 Fr. von Jung-Stilling, Ein Beitrag zur Livländischen Agrarstatistik. Aus dem material des livl. Landraths-Collegiums zusammengestellt und herausgegeben (Riga: 1881), 24.

54 Rosenberg, "1867.-1869. aasta näljahäda ja hädaabikomiteede tegevus", 338-339; Võitlus näljaga, 47-49, 251-252.

55 Lust, “Teraviljahinnad Eesti kohalikel turgudel”, 231. 
hakkamasaamist, kuid puudus oli suur, hakati korraldama eraalgatuslikku näljaabi hädaabikomiteede kaudu. ${ }^{56}$

Ikaldust on peetud alles 1866. aasta Balti vallaseadusega mõisa võimu alt vabastatud vallakogukondade esimeseks tõsisemaks proovikiviks. ${ }^{57}$ Seaduse järgi oli igas vallas vaja valida volikogu, mis oli kogukonna juhtorganiks. Olenevalt valla suurusest oli volikogu liikmete arv 4-24. Neist poole moodustasid maaga, teise poole aga maata talupojad. Valla eesotsas oli vallavanem (Eestimaal kutsuti teda talitajaks), kes oli kogukonna administratiiv- ja politseivõimu kandja. Vallavanemal võis olla kuni neli abilist. Vallavanem koos volikoguga pidi tegelema ikalduse tagajärgedega ja tagama vallaelanike varustamise viljaga.

Vene riigis rajanes toitluspoliitika viljavarude säilitamisel kohalikes magasiaitades, et ikalduste korral hoida ära näljahäda. Kivist magasiait pidi juba 19. sajandi esimesel poolel olema igas talurahvakogukonnas. 1866. aastal kehtestatud normide kohaselt pidi vallal iga meeshinge kohta olema varuks 1,5 setverti vilja. Häda korral võis magasiaidast toiduks või külviks kogukonnaliikmetele vilja laenata, kuid uudseviljast tuli laen koos protsentidega tagastada ${ }^{58}$ Headel aastatel oli vallal võimalik vilja ülejääki müüa ja sellest saadud raha vallalaekasse tallele panna. Kuna talurahva toiduga varustamise eest hoolitsemine oli pandud valla õlgadele, siis olenes olukorra lahendamine viljapuuduse suurusest ja valla majanduslikust seisust. Vallas kehtis riiklike koormiste täitmisel ühiskäenduse põhimõte. Seadus reguleeris magasiaitade ja vallakassa valitsemist ja vaestehoolekannet ning hädalistele laenuandmist. Vald oli kohustatud hoolitsema kõigi valla liikmete eest, eriti juhul, kui nad sattusid kas haiguste või vaesuse tõttu raskustesse. Kõigi valda puudutavate küsimuste lahendamine kuulus volikogu võimkonda, seega oli just volikogu see organ, mis pidi võtma vastu otsuseid magasiaida viljavarude kasutamise, laenu võtmise ja abi jagamise kohta. ${ }^{59}$

Kuna Eestimaal olid viletsad saagid juba 1865. ja 1867. aastal ja ka 1867.68. aasta talvel viitasid mitmed märgid (nt rukkioras oli lume tulekul nõrk) sellele, et rukkisaak võib tulla kesine, siis otsustati valdades kogutud

\footnotetext{
56 Rosenberg, "1867.-1869. aasta näljahäda ja hädaabikomiteede tegevus", 339; Lust, "Kui suured näljahädad tabasid eesti talurahvast 19. sajandil?”, 142-143; Võitlus näljaga, 51-52.$$
57 \text { Rosenberg, "1867.-1869. aasta näljahäda ja hädaabikomiteede tegevus", } 339 .
$$$$
58 \quad \text { Ibid., } 337 .
$$$$
59 \text { August Traat, "Vallareform Eestis 1866. aastal", Eesti NSV Teaduste Akadeemia. }
$$
Ühiskonnateadused 1968, 1, 21.
} 
magasivilja hoida ja seda mitte ära müüa. ${ }^{60} \mathrm{Ka}$ Eestimaa kuberner tegi juba 1867. aastal kihelkonnakohtunikele ülesandeks kanda hoolt, et vilja väljastataks magasiaitadest äärmise ettevaatusega ja vilja müük aitadest pandaks täielikult seisma. Seevastu Lõuna-Eestis, kus olukord oli tunduvalt parem, oli võimalik veel mõelda ka Eestimaa abistamisele. Näiteks otsustas Vana-Antsla vald 22. veebruaril 1868 saata rahaabi Eestimaa vaestele. Selleks müüdi magasivili oksjonil ja sel moel saadud raha saadeti kirikuorganisatsiooni kaudu Eestimaa abivajajatele. ${ }^{61}$ Vaeste heaks koguti armuande ja tehti korjandusi mujalgi Liivimaal. ${ }^{62}$

Erilist tähelepanu hakati pöörama vaesemate inimeste kindlustamisele peavarju ja toiduga. Esimesena pidid vaest toetama tema pere ja sugulased, kuid nende puudumisel langes vaene valla ülalpidamisele. Selliste nn vallavaeste ülalpidamine oli valla kohustus ja viletsatel aegadel olid nemad esimesed, kelle toitmise pidi vald tagama. ${ }^{63}$ Näljaabi norm oli 1868.-69. aastal madal, üks nael (409,5 grammi) vilja või leiba päevas. ${ }^{64}$ Iga vald pidi hea seisma selle eest, et vaesed saaksid piisavalt abi ja nad ei peaks puuduse pärast mujale kerjama minema. ${ }^{65}$ Kuigi väljaspool kogukonda oli kerjamine keelatud, liikus siiski talust talusse kerjuseid, kes püüdsid jõuda linnadesse, kus loodeti kergemalt abi saada. ${ }^{66}$ Kuusalu kirikukroonika andmeil tõusid hinnad pidevalt, kerjuste arv oli väga suur, hulkurite oma veel suurem, sagenesid vargused ning röövrünnakud maanteedel olid muutunud tavapärasteks. ${ }^{67}$ Kerjuste hulkumine mööda maad aitas kaasa ka nakkushaiguste (rõuged, sarlakid, tüüfus, düsenteeria) levikule ning hoogu sai väljarändamisliikumine Venemaale. ${ }^{68}$

Kuigi esmalt tekkis puudus vabadikel ja talud tulid viljaga toime, siis kevadel vajasid lisavilja mitmel pool ka talud, sest seemneviljast oli

60 RA, EAA.2915.1.1, 1. 2p: Jäneda vallavolikogu protokollid 1867-92; RA, EAA.3798.1.2, 1. 2: Atla vallatalitaja protokolliraamat 1868-80.

61 RA, EAA.3368.1.331, 1. 37: Vana-Antsla vallavolikogu protokollid 1866-79.

62 RA, EAA.3409.1.79, 1. 29p: Vastse-Antsla vallavolikogu protokollid 1866-80; Kuusalu kirikukroonika 1837-1914. Die Kirchenchronik von Kusal. Väljaandjad Prof. Dr. Albrecht Rost, Toomas Mäeväli (Kuusalu: 2014), 214.

63 RA, EAA.2608.1.30, 1. 42-42: Suuremõisa vallavolikogu protokollid 1866-78.

64 RA, EAA.3689.1.3, 1. 9: Vana-Suislepa vallavolikogu protokollid 1867-80; Lust, "Kui suured näljahädad tabasid eesti talurahvast 19. sajandil?", 143-144.

65 RA, EAA.2629.1.17a, 1. 6: Kõnnu valla talitaja protokolliraamat 1866-85.

66 Rosenberg, "1867.-1869. aasta näljahäda ja hädaabikomiteede tegevus", 341; RA, EAA.3882.2.16, 1. 20: Hulja valla talitaja protokollid 1866-92; Võitlus näljaga, dokument 83, 246; Kruus, Eesti ajaloo lugemik, 224.

67 Kuusalu kirikukroonika 1837-1914, 216.

68 Vahtre, "Ilmastikuoludest Eestis XVIII ja XIX sajandil", 130-131. 
puudus ${ }^{69}$ Kuna häda oli väga suur, enam eri talurahvarühmade (vabadikud, talurentnikud vastavalt koha suurusele) vahel vahet ei tehtudki, vaid rõhutati, et vald peab kõiki abivajajaid aitama. Riisiperes toonitasid valla volimehed 1868. aasta oktoobrikuus, et vald peab hoolitsema kõigi hädaliste eest, sest oma jõu ja nõuga jäävad kõik nälga. ${ }^{70}$ Kuna vald oli kohustatud hoolitsema oma valla liikmete eest, siis tekkis probleem vallas elavate teiste valdade liikmetega. Eelkõige puudutas see kroonumõisaid, kus maad olid jagatud väikekohtadeks teiste valdade liikmetest õigeusklikele. Sellistel juhtudel saadi abi heategevuslikelt ühendustelt. ${ }^{71}$

Keeruliste aegade üleelamiseks kasutati valdades eri meetodeid. Kuna mitmel pool tunti muret, et lastel ei ole võimalik nälja tõttu koolis käia, siis korraldati laste toitlustamine koolis. ${ }^{72}$ Raskete olude tõttu soovisid mitmed talud oma sulastele ja teenijatele koha üles ütelda, kuid vallavalitsuse otsusega ei lubatud neil seda teha, sest uut kohta oli võimatu leida ja inimesi ei saanud lageda taeva alla jätta. ${ }^{73}$ Mõnes vallas aitas raskustest üle saada mõis, mis pakkus hädalistele tööd ning laenas ka seemnevilja. ${ }^{74}$ Mitmel pool hakati magasiaita öösiti valvama, et seal vargusi ega rüüstamisi ei toimuks. ${ }^{75}$

Ikaldusaastatel loobuti valdades esimese abinõuna magasivilja ja selle intresside sissenõudmisest. Valla magasiaidast oli saanud omalaadne laenuasutus, mis talvel viljast tühjaks võeti ja kuhu talupojad pidid laenuks võetud vilja järgmisest saagist tagasi andma. Ikaldusaastatel ei toiminud magasilaenusüsteem korralikult, sest talupojad ei suutnud võlgu võetud vilja tagasi maksta, mistõttu tagavarad jäid aina väiksemaks. Ikalduse tõttu ammendati juba 1867.-68. aastal magasivilja varud peaaegu täielikult. Eriti raskeks kujunes 1868.-69. aasta, mil magasiait tühjenes puudust kannatavates piirkondades juba talvel. Oli selge, et seda magasiaidast saadud vilja ei suutud kõik ise tagasi maksta ja selle tagasimaksmine jäi kogu valla kanda. ${ }^{76}$

Kui magasivili oli laiali jagatud ja ait tühi, siis järgmiseks abinõuks oli vilja juurdeostmine valla säästude, nii kassas oleva raha kui ka obligatsioonide eest. Vallakassades hoiul olevad summad olid 1868. aasta augustikuus

69 RA, EAA.3977.1.1, 1. 6: Kloodi kogukonna protokollid 1866-70.

70 RA, EAA.2634.1.1: Riisipere vallatalitaja protokolliraamat 1868-88.

71 Võitlus näljaga, dokument 79, 234-238.

72 RA, EAA.4927.1.1, 1. 31: Sauga valla täiskogu, volikogu ja vallavalitsuse protokollid 1867-91.

73 RA, EAA.4626.1.1, 1. 56, 56p: Abja valla täiskogu ja volikogu protokollid 1867-73.

74 RA, EAA.4585.1.1, 1. 6: Tali vallavolikogu protokollid 1868-83.

75 RA, EAA.3977.1.1, 1. 5p: Kloodi kogukonna protokollid 1866-70.

76 RA, EAA.3141.1.1, 1. 4p-5: Leedi vallavolikogu protokollid 1867-82; RA, EAA.3458.1.1, 1. 4p: Vardi (Heimtali) vallavolikogu protokollid 1867-93. 
veel üsnagi märkimisväärsed: näiteks Eestimaal oli kokku 292655 rubla. $^{77}$ Kui enamasti osteti selle eest vilja, siis harvadel juhtudel laenati abivajajatele ka väiksemaid rahasummasid, mida tehti küll ainult üksikutes valdades. ${ }^{78}$ Mõnes vallas sellistest abinõudest piisaski, vald suutis sel moel raske aja üle elada ja ka oma hädalisi toita, ilma et tulnuks veelgi erakorralisemaid abinõusid tarvitusele võtta. See muidugi sõltus vallakassa seisust, mis võis suurel määral erineda. Nii nagu Põhja-Eestis, oli ka LõunaEestis mõne valla kassa tühi, kuid näiteks Leedi valla kassas oli 800 rubla, Avinurmel 2390 rubla ja Pollil 3000 rubla, mille eest osteti vilja. Räpina vallas realiseeriti vilja ostmiseks 1000 rubla väärtusega obligatsioon. Ka valla kassast võetud raha oli laen, mis tuli tagasi maksta ja mille puhul kehtis ühiskäenduse põhimõte: raha tuli tagasi maksta ka nende eest, kes seda ise teha ei suutnud.

Valla raha eest osteti vilja mõisatest ja naabervaldadest, kus olukord oli parem, näiteks ostis Kose-Uuemõisa vald vilja Albu vallast. ${ }^{79}$ Enamasti osteti vilja siiski linnadest, eelkõige Tallinnast, Tartust ja Pärnust, kuhu vili sisse toodi. Puudust kannatavad vallad saatsid esindajaid isegi Peterburi. Avinurme vallast läksid 1869. aasta kevadel sinna kolm meest (vallatalitaja, vöörmünder ja volikogu liige), kellest üks oskas vene keelt, mida oli vaja nii vilja ostmisel kui ka transpordi korraldamisel. Peterburist osteti 250 setverti rukist hinnaga 8 rubla ja 35 kopikat setvert, mis oli tunduvalt odavam kohapealsest viljast. Vili veeti kohale kolmes etapis: esmalt raudteel, sealt vankritel lotjadeni ja lotjadel Lohusuusse. Peamiselt transpordikulude tõttu tõusis viljaostu koguhind 2087 rublalt ja 50 kopikalt 2390 rublani. ${ }^{80}$ Pollis otsustati juba 1868 . aasta novembris paluda luba osta vallakassas olnud 3000 rubla eest vilja. Summast jätkus ka 1869. aasta maikuu lõpus veel 100 setverdi vilja ostmiseks. Esmalt saadeti vallavanem ja peakohtumees Tartusse ostu sooritama, hiljem voorimehed vilja valda vedama. ${ }^{81}$

Kõikjal siiski nendest abinõudest ei piisanud: eelkõige Põhja-Eestis ja Saaremaal on vallaprotokollides tõdetud, et terve vald on suure häda ja vaesuse sisse langenud ja kõik vaesed näljahädas. ${ }^{82}$ Näljahäda ulatust seal näitab asjaolu, et Saaremaal kasutati leivavilja ostmiseks ära 37 967,33 rubla

\footnotetext{
77 Rosenberg, “1867.-1869. aasta näljahäda ja hädaabikomiteede tegevus”, 338-339.

78 RA, EAA.2944.1.1, 1. 4: Väike-Kullamaa vallavolikogu protokollid 1866-90.

79 RA, EAA.2746.1.1, 1. 18-19: Uuemõisa kogukonna protokolliraamat 1866-81.

80 RA, EAA.3260.1.14, 1. 37p: Avinurme vallavolikogu protokollid.

81 RA, EAA.3555.1.30, 1. 19p-20, 21p-22: Polli vallavolikogu protokollid 1868-69.

82 RA, EAA.2631.1.1, 1. 2-3: Laitse vallavolikogu protokollid 1868-86; RA, EAA.3083.1.2, 1. 4, 10: Kaiu vallavanema otsuste protokollid 1867-89.
} 
vallakassade raha, kuid sellest ei piisanud. ${ }^{83}$ Kui vallal enam raha ei olnud, siis oli järgmiseks sammuks kroonult laenu taotlemine, et selle eest vilja hankida ja oma inimestele laenuks anda. Ametivõimud andsid juba varakult teada, et häda korral saavad vallad võtta laenu, aga rõhutasid, et see tuleb tagastada.

Vald võis magasivarusid ja vallakassa raha kasutada ning riiklikku toetuslaenu saada ainult kihelkonnakohtuniku nõusoleku alusel. Kihelkonnakohtuniku ülesanne oli juhtida valla ametimeeste tähelepanu nende kohustusele kindlustada kogukonna varustamine toiduainetega. ${ }^{84}$ Samal ajal oli ta ka võtmeisik, kellele vallad pidid tõestama, et neil puuduvad vahendid, et hoolitseda oma kogukonna liikmete ülalpidamise eest. ${ }^{85}$ Künnis loa küsimiseks oli üsna kõrge, sest enamasti oli vallal juba magasivõlgu ning kardeti uute võlgade tekkimist. ${ }^{86}$ Laenu võtmise otsust ei tehtud valdades kergekäeliselt, sest nii selle tagasimaksmist kui ka intresside tasumist peeti liiga koormavaks. ${ }^{87}$ Siiski oli valdav osa (63\%) valdadest, mille protokollid on sellest ajast säilinud, sunnitud kasutama kas vallakassas olevat raha või võtma vilja ostmiseks laenu.

Kroonult laenu võtmine tõusis päevakorda ikkagi alles väga suure häda korral, mil varud olid täiesti ammendunud. Kui varem oli puuduse korral pöördutud abipalvega mõisa või riigi poole, siis vallaseadusega oli vald muutunud majanduslikult täiesti iseseisvaks üksuseks. Vastavalt valla suurusele ja võimalustele tuli ette eri laenu võtmise taktikaid. Mõnes vallas oli tavaline, et olukorda hinnati iga kuu järel eraldi ja laenuks võeti korduvalt väiksemaid summasid, mis jäid vahemikku 10o-60o rubla (Järlepa). Teisal - eelkõige suuremates valdades - püüti kohe laenata suurem summa, mis ulatus 1000 rublast ülespoole. ${ }^{88}$ Eestimaal oli juba 1868 . aasta 15 . juuliks võtnud laenu suurem osa Harjumaa valdadest (79 valda), mille laenusummad ulatusid 50 rublast kuni 1500 rublani. Järvamaa, Virumaa ja Läänemaa valdadest olid tolleks ajaks laenu võtnud vähesed, kuid summa võis ulatuda isegi 3000 rublani. ${ }^{89}$ Laenuvajadus kasvas veelgi 1868 . aasta lõpus ja 1869. aasta esimesel poolel, mil oli puudu nii leivaviljast kui ka viljaseemnest. Kroonulaenu eest vastutas kogukond oma varaga. 1868. aastal

\footnotetext{
83 Lust, "Teraviljahinnad Eesti kohalikel turgudel”, 232-233.

84 Võitlus näljaga, dokument 56, 184.

85 Võitlus näljaga, 50; Võitlus näljaga, dokument 66, 207-208; dokument 67, 211.

86 RA, EAA.2718.1.1, 1. 9: Kassari (Keina) protokollid 1867-76.

87 RA, EAA.3794.1.3, 1. 4: Purila vallatalitaja protokoll 1867-83.

88 RA, EAA.3083.1.2, 1. 4: Kaiu vallavanema otsuste protokollid 1867-89; RA, EAA.2647.1.65, 1. 32: Jägala vallakogukonna protokollid 1867-70.

89 Võitlus näljaga, dokument 60, 193-105.
} 
võetud laenude tagasimaksmise tähtaeg oli enamasti kolm aastat, 1869. aastal aga juba kuus aastat. ${ }^{90}$ Vallas rakendus solidaarne vastutus, valla eestseisjad pidid jagama vastava summa valla maksejõuliste liikmete vahel ja selle neilt välja nõudma.

Laenu tagasimaksmine oli raske ja venis mõnel pool aastakümneteks, halvates aastateks valla majandusliku tegevuse. Nii näiteks konstateeritakse Raikkülas 1873. aasta oktoobris, et kirikutorni ei ole võimalik ehitada, sest näljaajal tehtud suurte võlgade maksmiseks ei ole jõudu ja ehitustöid saab ette võtta alles paremate aegade saabudes. ${ }^{91}$ Erinevalt Saaremaa valdadest tulid Eestimaa vallad riikliku toetuslaenu tagasimaksmisega toime, Saaremaal seevastu maksti laenu tagasi aastakümneid ja see tõi kaasa pankrotistumisi, mille käigus pandi võlglase vara oksjonile. ${ }^{92}$ Probleem oli aktuaalne veel 1891. aastal, mil Saaremaa talurahvaasjade komissar J. Kassatski nõudis näljaajal tehtud võlgade tasumist ja lükkas tagasi kuulujutud võlgade kustutamise kohta. ${ }^{93}$

Viletsate olude tõttu oli valdadel raskusi riigimaksude ja valla ametimeeste palkade tasumisega ${ }^{94}$ Tuli näiteks ette, et vallakassas olnud raha kasutati pearaha maksmiseks kõigi vallaliikmete eest. ${ }^{95}$ Enamasti jäigi pearaha maksmata, nii oli Eestimaal pearahamaksu võlgnevus 1869. aasta 1. septembri seisuga 239810 rubla 82,5 kopikat. ${ }^{96}$ Seisma jäid ka kõik suuremad tööd, nagu kavandatud kooli- või vallamaja ehitamine, mis lükati kaugemasse tulevikku. Ainult mõned üksikud vallad, kus madalseis ei olnud nii sügav, suutsid plaanitud töid ka ellu viia: näiteks ehitati Käravete vallas aastatel 1868-69 kohtumaja, mille ehituskulud võeti vallalaeka rahadest. ${ }^{97}$ Alles 1869 . aasta rahuldav saak andis võimaluse viljamagasite järkjärguliseks täitmiseks. Palamuse kirikukroonikas rõõmustatakse, et saak oli nii hea, et tühjenenud tagavaramagasinid sai jälle täita. ${ }^{98} 1870$. aastal avatud Peterburi-Tallinna raudtee lõi hea eelduse ka vilja sisseveoks.

Vallaametnikke on kritiseeritud puuduliku ja kallutatud tegutsemise ning ebapiisava näljaabi osutamise pärast. ${ }^{99}$ Samas puudus vallal vajalik

\footnotetext{
90 Võitlus näljaga, dokument 68, 212-215.

91 RA, EAA.3079.1.2, 1. 61: Raikküla vallakogukonna protokollid 1866-76.

92 Võitlus näljaga, dokument 85, 251, kommentaar 287, 47.

93 RA, EAA.2926.1.1, 1. 20-21p: Saaremaa talurahvaasjade komissari ringkiri, 17.04.1891.

94 RA, EAA.3525.1.5, 1. 5p, 8: Väike-Kõpu vallavolikogu protokollid 1864-69.

95 RA, EAA.5171.1.21, l. 1: Illuka vallavolikogu protokollid.

96 Võitlus näljaga, dokument 85, 250.

97 RA, EAA.2912.1.1, 1. 3p, 8p: Käravete (Ambla) valla volikogu protokollid 1866-88.

98 Palamuse kiriku ja kihelkonna kroonika (Tartu: 1997), 118.

99 Lust, "19. sajandi näljahädad Eestis", 45-46; Lust, "Kui suured näljahädad tabasid eesti talurahvast 19. sajandil?", 143-144.
} 
jõud, et kõigi ülesannetega toime tulla. Valla varud olid piiratud ja puudusid võimalused korraldada nende ümberjagamist valdade vahel. Vald sai kasutada magasivarusid ja võtta vallakassast vilja ostmiseks raha, kuid sellega võimalused ka piirdusid. Lisaks oli vaja laenu võtmisel hinnata valla suutlikkust seda koos protsentidega tagasi maksta. Suurema näljahädaga toimetulekuks ei piisanud valla kasutuses olnud vahenditest.

Eestis on rõhutatud poliitilisi ja majanduslikke tingimusi, mis tegid võimalikuks nii suure näljahäda puhkemise, vähem aga vananenud maakasutussüsteemi mõju, nagu eespool mainitud ribapõllud, mis piiras talusid jäikade maakasutuse tingimustega ega võimaldanud neil üle minna viljavaheldusele või kasutusele võtta uuenduslikke põlluharimisviise. Ribapõldude süsteem kaotati seoses talude kruntimõõtmisega. ${ }^{100}$ Oma krunt tähendas talu jaoks suurt tööjõu kokkuhoidu ja võimaldas parandada põlluviljakust. Iga talu sai ise oma makkasutuse üle otsustada, parandada maaharimise kvaliteeti ja sobiva maa olemasolu korral oma põlde laiendada. Üleminek viljavaheldusele võimaldas võtta külvikorda uusi kultuure.

Järgnevalt on pööratud tähelepanu nendele valdadele, kus 1860. aastate teiseks pooleks olid maad juba krunditud, et välja selgitada, milline oli seal olukord ja milliseid abinõusid oli viljapuuduse leevendamiseks vaja kasutusele võtta. Eestimaal oli kruntimine juba 1840. aastatel läbi viidud Munalaskme mõisas ${ }^{101}$, kuid kahjuks ei ole Munalaskme valla arhiiv säilinud. Näljaajast puuduvad protokollid ka teistest Eestimaa valdadest (Kodasoo, Saku), kus kruntimine oli selleks ajaks juba tehtud. Liivimaal oli selleks ajaks kruntimõõtmine toimunud juba mitmetes Pärnu- ja Viljandimaa era- ja riigimõisates (Kilingi, Vana- ja Uue-Suislepa, Vooru, Abja, Jäärja, Vana-Pornuse, Vana-Kariste, Vana-Põltsamaa, Kärstna, Uue-Pornuse). ${ }^{102}$ Enamasti olid need mõisad, kus suurem osa talusid asus juba vanast ajast hajali või väikeste rühmadena ja nende valdused olid juba enne kruntimistki suhteliselt kompaktselt eraldatud.

Ebasoodsate ilmastikuolude ja ikalduse eest ei olnud muidugi kaitstud ka krunditud ja päriseksostetud taludega piirkonnad, kuid neil olid siiski paremad võimalused viljapuudusega toime tulla. Abja vallas oli saak 1868. aastal vilets, mistõttu vallavolikogu otsustas 1868 . aasta sügisel loobuda magasivilja võlgade sissenõudmisest. Kuna seal oli palju väljaostetud

\footnotetext{
100 Gea Troska, Eesti külad XIX sajandil. Ajaloolis-etnograafiline uurimus (Tallinn: Eesti Raamat, 1987), 55-6o.

101 C. A. v. Hueck, Das Gut Munnalas in Estland und meine Bewirtschaftung desselben in den Jahren 1838 bis 1845 (Reval: F. Kluge, 1845), 50-54, 65-67.

102 Gea Troska, "Talumaade kruntimisest Eestis 19. sajandil”, Eesti NSV Teaduste Akadeemia Toimetised. Ühiskonnateadused, 35/1 (1986), 66-67.
} 
talusid, siis pidid nad ise laenu võtma ja vilja juurde ostma. ${ }^{103}$ Vana-Suislepa vallas otsustati juba 1868. aasta aprillis, et kokkuhoiu mõttes valla ametimeestele (vallavanem, vöörmündrid, kohtumehed) palka ei maksta, sest nad olid kõik taluperemehed, kes tulid palgatagi toime. ${ }^{104}$ Raskete olude tõttu peeti vajalikuks 1869. aasta veebruaris kindlaks määrata magasiaidast väljaantava viljalaenu suurus, mida tehti talu taalriväärtuse alusel. Samal ajal otsustati, et vald laseb vaeste jaoks mõeldud vilja jahvatada ja annab igale vaesel ühe naela leiba päevas kuni 1869. aasta augustini, seega uue lõikuseni. ${ }^{105}$ Jäärja vald oli sunnitud 1869. aasta maikuus siiski laenu võtma, sest vallakassast oli raha ära varastatud. Kui enamasti ostis vald laenuks saadud raha eest ise vilja ja jagas selle abivajajatele, siis Jäärjas antigi abi rahas. ${ }^{106}$

Andmete vähesus ja korraliku võrdlusmaterjali puudumine ei võimalda kindlalt järeldada, et krunditud ja väljaostetud talud said viletsama saagiga ajal paremini hakkama, sest need kõik paiknesid Põhja-Liivimaa lõunaosas, kus olukord ei olnud nii katastroofiline kui Eestimaal ja Saaremaal. Siiski võimaldavad ka need vähesed andmed tõsta esile viljapuuduse leevendamiseks kasutatud teistsuguseid meetmeid. Esimeseks abinõuks oli kulude kokkuhoid valla ametimeeste palkade pealt. Selgelt ilmneb ka rahamajanduse suurem levik selles piirkonnas. Väljaostetud talud pidid ise vajaduse korral laenu võtma ja vilja juurde ostma ning ka laenuks saadud raha jagati abivajajatele. Enamasti aitasid olukorda parandada väiksemad abinõud, nt väljaantava magasilaenu normeerimine ja magasivõlgade sissenõudmisest loobumine. Riigilt küsiti laenu erakordsetel juhtudel.

\section{Kokkuvõte}

Teraviljakülvi ja saakide suuruse ning kartulikasvatuse kohta Eestimaal ja Põhja-Liivimaal on võimalik leida andmeid kuberneride aastaaruannete lisadest. Kui saagikusele on varasemates uurimustes pööratud suurt tähelepanu, siis saakide suurus on jäänud tähelepanuta, sest nende andmete usaldusväärsus on kõikuv. Siinses artiklis on parema allikmaterjali puudumise tõttu esitatud külvi ja saakide suurus kuberneride aruannetele tuginedes, sest see võimaldab võrrelda eri piirkondade olusid ja pöörata tähelepanu saagi suurusele inimese kohta, mis annab samuti hea võimaluse

\footnotetext{
103 RA, EAA.4626.1.1., 1. 54: Abja valla täiskogu ja volikogu protokollid 1867-73.

104 RA, EAA.3689.1.2, 1. 6: Vana-Suiselpa vallavolikogu protokollid 1867-80.

105 Ibid., 1. 9-11.

106 RA, EAA.3757.1.2, 1. 9-10: Jäärja vallavolikogu protokollid 1868-74.
} 
olude kõrvutamiseks. Inimese aastaseks toiduvajaduseks arvestati sel ajal 1 setvert tali- ja 1 setvert suvivilja. Eestimaal saadi rukist sellest normist vähem (o,8 setverti inimese kohta) nii 1865., 1867. kui ka kaudsetele andmetele tuginedes 1868. aastal. Põhja-Liivimaal oli headel aastatel saak inimese kohta kõrgem kui Eestimaal, kuid rukkisaak jäi alla normi $(0,9)$ 1865., 1867., 1868. ja 1870. aastal. Eriti vilets oli olukord 1868. aastal Saaremaal, kus rukki kogutoodang inimese kohta oli ainult o,6 setverti. Suure kroonumõisate osakaaluga Saaremaal ja Pärnumaal olid võrreldes teiste Põhja-Liivimaa maakondadega nii rukki- kui ka kartulisaak 1868. aastal inimese kohta kõige väiksemad.

Kuna vald pidi hoolitsema vallaliikmete toiduga varustamise eest, siis sõltus valla tegevus ühelt poolt viljasaagi suurusest ja teiselt poolt valla majanduslikust olukorrast. Palju olenes sellest, milline oli olukord ikaldusele eelnenud aastatel, kui palju oli magasiaidas vilja ja kui palju tekkis lisaks vallavaestele neid, kes samuti vajasid raskel ajal valla abi. Need vallad, kellel oli magasiait täis ja kassas raha, said rasketel aegadel paremini hakkama. Vallalaeka raha eest osteti linnast või mõisast vilja, mis jagati kõigi abivajajate vahel. Vilja anti enamasti toiduks, kuid seemnevilja puuduse korral ka külviks. Vallast saadud abi oli samuti laen ja kuna kehtis kollektiivne vastutus, siis jagati tekkinud võlg maksujõuliste valla liikmete vahel ära. Vaesemad ja viletsamate tagavaradega vallad olid sunnitud võtma riigi käest laenu, mille summad võisid ulatuda paari tuhande rublani. Riigile võla tagasimaksmine jäi vallale järgnevatel aastatel raskeks koormaks ja võis mõnel pool (eelkõige Saaremaal) venida isegi paarikümne aasta peale.

Märgatavad piirkondlikud erinevused viljasaakide suuruses 19. sajandi keskpaiku annavad tunnistust looduslike ja klimaatiliste tegurite tähtsusest. Valitsev olukord maakasutuses ja põllumajanduses üldisemalt ei soodustanud talurahva hakkamasaamist ikalduse korral. Kuigi 1860. aastatel toimus üleminek raharendile ja mõisates palgalise tööjõu kasutamisele, olid muutused talumajanduses aeglased. Alles uute majandussuhete kindlustumine, eelkõige talude kruntimõõtmine ja talupoegliku väikemaavalduse kasv, lõid eeldused üleminekuks viljavaheldusele ja rahamajandusele, mis tagas parema toimetuleku ka ilmastiku poolest viletsamatel aastatel. 


\section{AвSTRACT: Measures for alleviating grain shortages in Estland's and Northern Livland's rural municipalities in the $1860 \mathrm{~s}$}

This article is part of a joint project conducted by Finnish and Estonian scholars that aims to comparatively study the famine of the 1860 os in those countries. Unlike Finland, research into the last large-scale famine of the $19^{\text {th }}$ century has begun only rather recently in Estonia. Kersti Lust has contributed the most to this area of research. The task of this article is to trace the development of agriculture in the present-day Estonian area in the 1860 s, focusing primarily on the size of harvests. Attention is paid to some factors that still made agriculture vulnerable even in the 1860s. Additionally, the article also considers methods adopted at the local level in attempts to resolve the situation, alleviate food shortages, and ward off famine.

The appendices to the annual reports drawn up by the governors general of Estland and Livland include statistical data on the amounts of winter grain (rye), summer grains (barley, oats) and potatoes sowed, the size of their harvests (in chetverts), and the number of inhabitants. These appendices also provide an estimate of crop yields (how many seeds these types of crops produced). The fact that more precise information from Estland on 1868 is missing has to be pointed out as the largest gap. In spite of imperfection, the absolute numbers presented in the appendices of the reports from the governors are used in this article since there are no better options.

The archives of rural municipal governments provide the opportunity to ascertain how different localities tried to alleviate the situation that emerged as the result of crop failure and to ensure that all members of the rural municipality were supplied with grain. The extent of crop failure, the use of communal grain, and the purchase of grain using money from the rural municipal treasury or on loan unfold from rural municipal council transcripts. Many archives of rural municipal governments have been lost over time. There are only 156 collections in total that contain transcripts from 1868 and 1869.

The most important grain was rye, which could withstand poor growing conditions. The amount of winter grains sowed in Estonian territory as a whole was around 200,000 chetverts in the 1860 s, and in the better years, the harvest of winter grains exceeded the threshold of 1,000,0oo chetverts. The average crop yield of winter grains was 4.8 in the 1860 os (excluding 1868). Barley and oats were primarily grown as summer grains, whereas oats were mostly used as animal feed. 
It was only starting in the 1830 s that potato cultivation had begun spreading more extensively in the Baltic region, whereas it started being used primarily in distilleries, where it was cheaper raw material compared to rye. Unlike grains, potatoes were cultivated considerably less in Livland than in Estland. The potato harvest failed in Estland in 1866 and 1867, when the crop yield was only 2.8. The crop nevertheless did not fail in 1868 in the northern part of Livland as a whole, but it was poor (the crop yield was 3.4). Good potato harvests in Estland in both 1869 and 1870, when it set a record, surpassing the 662,000 chetvert threshold, contributed to recovery from the famine.

Crop failure (less than three seeds) was not universal, rather it affected only one crop type and was mostly regional. In Northern Estonia and primarily in Saaremaa, the years of poor harvests in 1865 and 1867 were followed by the rainy summer of 1868 , which brought with it crop failure and famine. The most complicated situation was in Saaremaa because the soil there was not very fertile. There winter grain yielded 2 seeds, summer grains 2.5 and potatoes 0.5 seeds. Thus, less potatoes were harvested there than were planted. Tartu County was the only district in Livland where average or satisfactory, and even good harvests were almost consistently achieved in the 1860 .

Grain grown in Estland and Northern Livland was mostly consumed in the domestic market. Manorial estates cultivated grain primarily with the needs of the market in mind, while farms had to look after covering their own needs first and foremost. At that time, 1 chetvert of winter grain and 1 chetvert of summer grains was considered the food requirement of one person for a year. In Estland, 1.1-1.7 chetverts of rye and 1.2-2.2 chetverts of summer grains were produced per inhabitant in the 1860s. Rye was produced in quantities below this norm (0.8) in 1865, 1867, as well as in 1868 , according to indirect data. In Northern Livland, 1-1.4 chetverts of rye and 1.1-2.o chetverts of summer grains were produced per inhabitant. There production of rye was slightly below the norm (o.9) in 1865 , 1867,1868 and also in 1870. Although crop yield was higher in Northern Livland, the large number of very small holdings in the crown manorial estates there, where secondary livelihoods, primarily fishing, occupied an important place, caused lower indices per person. The rye harvest per person was lowest in Pärnu County and Saaremaa (o.6) in 1868. The relative proportion of crown manors was especially large in these two counties. 
Alongside harvests and crop yields, it is also necessary to examine how the population coped in situations of crop failure and hunger, and what measures were taken for alleviating grain shortages.

This particular crop failure was the first serious touchstone for the rural municipal communities that had only just been liberated from the control of the manorial estates by the Baltic Rural Municipalities Act in 1866. According to this act, each rural municipal community had to elect a council, which was the governing body of the rural municipal community. Thus, the council was the body that had to make the decisions concerning the use of the communal granary's grain reserves, the taking out of loans, and distributing aid.

Harvests in many regions of Estland and Northern Livland, and especially in Saaremaa, were so small in 1868 as the result of crop failure that they did not make it possible to survive over the winter or to allocate grain for the next sowing. The crisis reached its culmination in the winter of 1868 and the spring of 1869, when famine struck the most backward regions, gripping the province of Estland more or less as a whole, whereas the situation in Lääne County was the worst. Of the counties of the northern part of Livland, it struck only Saaremaa severely. Epidemics broke out in addition to the famine, primarily typhus, as well as dysentery, measles, smallpox, etc.

The rural municipality was obliged to care for all its members, especially if they encountered difficulties due to either illness or poverty. Particular attention started being paid to providing poorer people with food and shelter. Food supply policy in the Russian state was founded on maintaining reserves in local communal granaries in order to prevent famine in the event of crop failure. In an emergency, members of the community could borrow grain from the granary for food or sowing, but the borrowed grain had to be returned together with interest in the form of grain from the new crop. In good years, the rural municipality could sell the surplus grain and set aside the money earned from such sales in the rural municipal treasury.

When the communal granary's grain reserves had been distributed and the granary was empty, the next measure was to purchase additional grain in return for the savings of the rural municipality, using both money from the treasury as well as obligations. In some rural municipalities, such measures were sufficient, and the rural municipality managed in this way to ride out this difficult period and also to feed its poor. More exceptional measures did not have to be adopted. This, of course, depended on the condition of the rural municipal treasury, which differed widely. Money taken 
from the rural municipal treasury was also a loan that had to be paid back. Here the principle of joint surety applied, thus this also had to be paid back on behalf of those who were themselves incapable of doing so.

These measures nevertheless were not sufficient everywhere because primarily in Northern Estonia and Saaremaa, rural municipality transcripts record that the whole rural municipality had declined into great need and poverty, and all of the poor were starving. If the rural municipality had spent its own financial resources, the next step was to apply for a crown loan with which to procure grain, which would in turn be loaned out to the people of the rural municipality. The public authorities already made it known well in advance that rural municipalities could take out loans in an emergency, stressing that this was not aid and that it had to be paid back.

The rural municipality could use granary reserves and money from the rural municipal treasury and receive support loans from the state only with the consent of the parish judge. The threshold for requesting permission was quite high because rural municipalities mostly already had communal granary debts, and the authorities feared the creation of new debts. The decision to take out a loan was not taken lightly in the rural municipalities because both paying back the loan and the payment of interest were considered to be too difficult.

Taking out a crown loan was placed on the agenda only in the event of a very serious emergency, when reserves were completely depleted. The need for loans continued to grow at the end of 1868 and over the first half of 1869 , when there were shortages of bread grains as well as seed grain.

Different types of tactics can be seen in the case of taking out loans that corresponded to the size and opportunities of the rural municipality. In some rural municipalities, it was common procedure to assess the situation separately for each month, and smaller sums within the range of 100-600 roubles were taken out repeatedly as loans. Elsewhere - primarily in larger rural municipalities - the aim was to borrow a larger sum all at once that exceeded 1,00o roubles. A small proportion of the rural municipalities in Järva, Viru and Lääne counties had taken out a loan by then, but the sum could even extend to 3,000 roubles.

Since the rural municipalities had been made responsible for looking after supplying the peasantry with food, resolving the situation depended on the extent of the famine and the economic condition of the rural municipality. At the same time, the rural municipality lacked sufficient power for coping with the tasks assigned to it. The resources of the rural municipality were limited, and it did not have possibilities for redistributing reserves 
between rural municipalities. In cases of more serious famine when communal granary reserves were insufficient, the manorial estate and, above all, the state had the means for assisting the population.

Grain harvests did not depend solely upon the weather or other natural conditions, but also on agrarian relations. The farm economy was still almost entirely dependent on the manorial estate economy in the 1860 . Major changes took place in the 186 os aimed at accelerating the transition from the mode of management based on corvée to a system based on a money economy. The reorganisation of relations between farm and manorial estate did not immediately bring any noticeable changes. The three-field system remained in use in compact hamlets with fields divided into strips in Estland and Saaremaa until the enclosure of farms, which was usually carried out just before the manor put the farms up for sale.

Enclosure became universal in the latter half of the $19^{\text {th }}$ century, when the sale of farmland to peasants as hereditary property became its primary impetus. The outright purchase of farms took place early in Livland precisely in those areas with predominantly dispersed settlement where farms had accumulated money from the sale of flax and where it was not necessary to carry out the enclosure of farms before starting to sell farms. At the same time, this is precisely what led to Northern Livland's more rapid commercial and financial development compared to Estland. Areas with enclosed farms that had been purchased outright were naturally not immune to unfavourable weather conditions and crop failure. They nevertheless had better chances for coping with grain shortages. Only the establishment of new economic relations, primarily the enclosure of farms and the growth of peasant smallholdings, created the prerequisites for the transition to crop rotation and for increased crop yields, which made it possible to cope better with setbacks.

KeYwORDs: agriculture; famine; Russian Empire; Estonia

Ülle Tarkiainen is researcher at the Estonian National Archives.*

* Correspondence: National Archives, Nooruse 3, Tartu 50411, Estonia. E-mail: Ylle.Tarkiainen@ra.ee 